\title{
Early Pennsylvanian Odonatoptera from the Xiaheyan locality (Ningxia, China): new material, taxa, and perspectives
}

\author{
Yongjun $\mathrm{Li}^{1,2}$, Olivier Béthoux ${ }^{3}$, Hong Pang ${ }^{2}$ and Dong Ren ${ }^{*}, 1$ \\ ${ }^{1}$ College of Life Science, Capital Normal University, 105 Xisanhuanbeilu, Haidian District, Beijing 100048, China. \\ E-mails: liyongjun_sysu@126.com,rendong@mail.cnu.edu.cn \\ ${ }^{2}$ State Key Laboratory of Biocontrol and Institute of Entomology, Sun Yat-Sen University, Guangzhou 510275, China. \\ E-mails: liyongjun_sysu@126.com, lsshpang@mail.sysu.edu.cn \\ ${ }^{3}$ UMR7207 CNRS (CR2P), Museum National d'Histoire Naturelle, CP38, 8 rue Buffon, 75231 Paris Cedex 05, France. E-mail: obethoux@mnhn.fr
}

Received 20 April 2012

Accepted 1 September 2012

Published 20 February 2013

\section{Key Words}

\section{Odonata}

Meganeuridae

Late Carboniferous

Permian

Size range

Gigantism

Food web

\begin{abstract}
Data on Odonatoptera species from the Xiaheyan locality (Ningxia, China; Early Pennsylvanian) described so far are complemented based on abundant new material. Several taxonomic and nomenclatural adjustments are proposed. The species Tupus readi Carpenter, 1933 is transferred to the genus Shenzhousia Zhang \& Hong, 2006 in Zhang et al. (2006), and therefore should be referred to as Shenzhousia readi (Carpenter, 1933) n. comb. The monotypic genus Sinomeganeura Ren et al., 2008 is synonymized with Oligotypus Carpenter, 1931. As a consequence the type species of the former must be referred to as Oligotypus huangheensis (Ren et al., 2008) n. comb. The monotypic genus Paragilsonia Zhang, Hong \& Su, 2012 in Su et al. (2012) is synonymized with Tupus Sellards, 1906. As a consequence the type-species of the former is to be referred to as Tupus orientalis (Zhang, Hong \& Su, 2012 in Su et al. (2012)) n. comb. The monotypic genus Sinierasiptera Zhang, Hong \& Su, 2012 in Su et al. (2012) is synonymized with Erasipterella Brauckmann, 1983. As a consequence the type-species of the former is to be referred to as Erasipterella jini (Zhang, Hong \& Su, 2012 in Su et al. (2012)) n. comb. In addition Aseripterella sinensis n. gen. et sp. and Sylphalula laliquei $\mathrm{n}$. gen. et $\mathrm{sp}$. are described. The 'strong oblique distal' cross-vein, located in the area between RA and RP is found to occur more extensively than previously expected. It is believed to be a structure distinct from the subnodal cross-vein, and therefore deserves to be referred to by a distinct name (viz. 'postsubnodal cross-vein'). Odonatoptera from the Xiaheyan locality cover a broad range of sizes. Factors that could have promoted the evolution of large-sized Odonatoptera are briefly reviewed. The permissive conditions prevailing during the Pennsylvanian, and the existence of an elaborated food web, are emphasized as putative positive factors. The new taxonomic treatment suggests that genera documented in the Lower Permian, such as Shenzhousia and Oligotypus, stem from the early Pennsylvanian, and implies a high resilience of these taxa when facing the Pennsylvanian-Permian environmental perturbations.
\end{abstract}

\section{Introduction}

Thanks to its abundance, the material yielded by the recently discovered Pennsylvanian Xiaheyan locality (Ningxia Province, China) significantly improved our knowledge of the entomofauna of this period, in particular regarding intra-specific variability (Béthoux et al.
2011; Cui et al. 2011; Gu et al. 2011). Many species remain to be described, and data on several of the species described initially is to be implemented. This is particularly true of the very frequent and diverse archaeorthopterans [i.e. stem-Orthoptera; apart from $\mathrm{Gu}$ et al. (2011), see preliminary works by Prokop \& Ren (2007), and Liu et al. (2009)], but applies also to the

* Corresponding author 
somewhat rarer Odonatoptera, a group including dragon-, damsel-, and griffenflies. The latter is the focus of the current contribution.

To date four odonatopteran species have been described from the Xiaheyan locality, namely Shenzhousia qilianshanensis Zhang \& Hong, 2006 in Zhang et al. (2006), Sinomeganeura huangheensis Ren et al., 2008, Paragilsonia orientalis Zhang, Hong \& Su, 2012 in Su et al. (2012), and Sinierasiptera jini Zhang, Hong \& $\mathrm{Su}, 2012$ in $\mathrm{Su}$ et al. (2012) (the last three species are re-assigned below). Without exception these species are documented based on a few and incomplete specimens. The abundant material collected by the research team of DR and described in the following will allow us to significantly complement data on these species, and reconsider their taxonomic position. In addition we describe two new species from this locality. Among other inputs, our systematic treatment indicates that Pennsylvanian and Early Permian odonatopteran faunas had compositions closer than previously estimated.

\section{Material and methods}

Specimens which number begins with the acronym GMC are housed at the Geological Museum of China (Beijing, China). Other specimens are housed at the Key Lab of Insect Evolution and Environmental Changes, College of Life Sciences, Capital Normal University (CNU; Beijing, China; Ren Dong, Curator). All specimens were collected from the locality near Xiaheyan village (Zhongwei City, Ningxia Hui Autonomous Region, China), belonging to the Tupo Formation, and are of Namurian age (Early Pennsylvanian), as currently estimated (Lu et al. 2002; Zhang et al. in press). Provided size ranges could be over-estimated due to the plastic deformation that affected the material from the locality (Cui et al. 2011; Gu et al. 2011).

In several specimens veins elevation is poorly preserved. As a consequence vein intercalaries cannot be distinguished from actual branches of main veins (the former have an elevation opposed to that of the latter). We propose to refer to the former as 'putative intercalaries'. In the case of the specimen CNU-NX1-452, another consequence is that positive and negative imprints cannot be determined.

Specimens were examined using a LEICA MZ12.5 dissecting microscope and illustrated with the aid of a drawing tube. Photographs were taken using a Canon EOS 450D/550D digital camera coupled to a Canon $50 \mathrm{~mm}$ macro lens (and an extension tube as appropriate), or a Canon MP-E $65 \mathrm{~mm}$ macro lens (all lenses equipped with polarizing filters). Unless specified photographs reproduced on Figs 1-8 are combinations of photographs of a specimen both dry and immersed in ethanol.

Vein abbreviations are as follows: ScA/ScP, Subcosta anterior/posterior; R, Radius; RA/RP, Radius anterior/posterior; MA/MP, Media anterior/posterior; $\mathrm{Cu}$, Cubitus; $\mathrm{CuA} / \mathrm{CuP}$, Cubitus anterior/posterior; AA/AP, anterior/posterior Analis. Because MA runs parallel and close to $\mathrm{R}$ in Odonatoptera, RP has not evident independent origin. The terms 'CuA-crossing' and 'CuP-crossing' refer to the stems of $\mathrm{CuA}$ and $\mathrm{CuP}$ diverging from $\mathrm{MP}+\mathrm{Cu}$ and fusing with $\mathrm{AA}$, near wing base. The label 'Ax0' indicates the first antenodal cross-vein.

Due to the high frequency of faults characteristic of the outcrop, only fragmentary specimens were collected. However most species were sampled based on several fragments, allowing us to provide more or less complete reconstructions. 'Additions' to actual specimens are duly indicated in figure captions, and reproduced in gray. For example the left part of the reconstruction represented on Figure $4 \mathrm{~B}$ and reproduced in gray was generated based on the reconstruction repre- sented on Figure 4A. In order to generate these 'additions', it was postulated that specimens could have undergone an elongation of factor 1.2 (elongation axis irrespective of wing axis), as a consequence of plastic deformation (already reported to have applied in this locality; Cui et al. 2011; Gu et al. 2011). This practice will allow the reader to critically appreciate the available data.

In places, for species which generic assignment is discussed, we propose to use Lanham's species names (Lanham 1965; elsewhere referred to as uninominal species names). Advantages of this approach with respect to the traditional binominals have been highlighted elsewhere (Dayrat et al. 2004; Dayrat \& Gosliner 2005; Béthoux 2010; Béthoux \& Jarzembowski 2010). This option was chosen to ease the taxonomic discussion only. For example, the species orientalis Zhang, Hong \& Su, 2012 in Su et al. (2012) was originally assigned to the monotypic genus Paragilsonia. Below we argue that the pre-existing genus Tupus is a suitable pigeonhole for the species. The statement 'Paragilsonia orientalis belongs to Tupus' in nonsensical, as a consequence of self-contradiction. In such case the recourse to Lanham's species name allows us to refer to the species as 'orientalis' until its assignement to Tupus is proposed, without generating nonsensical statements. It must be emphasized that the use of a Lanham's species name is abandoned in the text as soon as the discussion on the taxonomic position of the corresponding species is completed (unless nonsensical). Apart from this aspect, in agreement between the authors, the traditional nomenclatural procedure is followed herein. This does not imply support for this approach on the part of OB.

\section{Systematic Palaeontology}

\section{Superorder Odonatoptera Martynov, 1932}

Discussion. Several of the species described in the following could be assigned to the taxon Meganisoptera Martynov, 1932, considered as of ordinal level by $\mathrm{Nel}$ et al. (2009). However decisive diagnostic characters of the group are not evident. Nel et al. (2009) discussed characters proposed by Bechly $(1996,2007)$ in support of this group and challenged the relevance of all of them except for "crowding of longitudinal veins along the costal margin". According to Nel et al. (2009, p. 93) it "remains the best synapomorphy for the Meganisoptera". However having ScA, ScP, RA, and the main stem of RP (in addition to presumed $\mathrm{C}$ system fused with the anterior margin) running along the anterior wing margin is not unique to these Odonatoptera, as it is also occurring in many Palaeodictyoptera, such as representatives of the family Eugereonidae (among others, see Kukalová 1969). The relatively vague formulation of the character could even apply to the wing morphology of the Megasecoptera (extinct order; Carpenter 1992), and to the Triplosidae (extinct Ephemeroptera or Palaeodictyoptera; Prokop \& Nel 2009). Indeed it applies to any insect whose wings are elongate, and with a basal origin of RP, such as many Mantodea (praying mantises; Béthoux \& Wieland 2009). More importantly, it applies to a large number of Odonatoptera (all?; among others, see Carpenter 1992) and therefore is possibly a symplesiomorphy at the level of this group. Under these circumstances, and provided the primary aim of this contribution (viz. describe the diverse Pennsylvanian Odonatoptera from Ningxia), we propose to take a cautious stand and avoid the formal 
use of the name 'Meganisoptera' as that of a valid taxon.

Familial diagnoses and delimitation of meganisopteran Odonatoptera as discussed by Nel et al. (2009) are of difficult use too. For a large part this situation is the consequence of the incomplete documentation of many fossil species, often represented by very incomplete wings, and/or few specimens. However $\mathrm{Nel}$ et al. (2009) diagnoses are sometimes problematic on their own. For example " $\mathrm{CuP}$ with more than eight posterior branches, covering a very long area that is distinctly longer than that of $\mathrm{CuA}$ " is listed as diagnostic of Paralogidae (p. 94). However, according to Carpenter (1960, text-fig. 2), Paralogus aeschnoides Scudder, 1893, typespecies of the type-genus of the family, possesses a $\mathrm{CuP}$ with barely more than six branches, and which area along the wing margin is of similar size as that of $\mathrm{CuA}$. As for the Meganeuridae, as clearly stated in the Remark section of the family Kohlwaldiidae in Nel et al. (2009, p. 95), the oblique cross-vein in the area between RA and RP and located close to the origin of $\mathrm{RP} 2$, observed in meganeuridaean, is considered as "typical" of the family Meganeuridae (and as the only useful diagnostic character). However, based on new data on material from Xiaheyan ( $\mathrm{Su}$ et al. 2012; and below), and literature data (see Discussion), it is clear that this trait is more widespread among Odonatoptera than presumed by Nel et al. (2009). At this stage suffices to add the quote "The exact relationships between the Meganeuridae and Kohlwaldiidae are impossible to establish at this stage" ( $\mathrm{Nel}$ et al. 2009, p. 95) to support the view that the current familial classification of meganisopteran Odonatoptera is unsatisfactory. Therefore we will not formally use the familial ranks in the following for the 'meganisopteran' species, and will attempt to use the generic level only.

\section{Shenzhousia Zhang \& Hong, 2006 in Zhang et al. (2006)}

Composition. Sh. qilianshansensis Zhang et al., 2006 (type-species), Sh. readi (Carpenter, 1933) n. comb.

Commented diagnosis. Zhang et al. (2006) list as diagnostic of the genus Shenzhousia the following character states: (1) "ScP short", (2) "RP forking basally", (3) "RP1 + 2 and RP3 + 4 close and parallel to each other for a long distance with only one row of cell [sic] between them, then diverging gradually after midwing". Our observations of new material of the type species (viz. Sh. qilianshansensis) demonstrate that $\mathrm{ScP}$ is long rather than short (Fig. 1B), alike virtually all meganisopterans (Carpenter 1939, figs 6-7; Zessin 1983, fig. 3; Grimaldi \& Engel 2005, figs 6.25, 6.27; Nel et al. 2009; among others). The character state (2) is not unique to the type species, as it was said to be diagnostic of the Lower Permian species readi Carpenter, 1933 by Carpenter $(1939$, p. 39) [a species up to now assigned to the genus Tupus Sellards, 1906; Nel et al. (2009)]. Finally, as formulated, the character state (3) applies to virtually all meganisopterans (ibid.), and could even be correlated to the character state (2).

Finally the character 'RP forking basally' is the only truly diagnostic trait of this genus. Because many fossil specimens preserve a portion of wings only, the formulation ' $R P$ stem (from its origin from $\mathrm{RP}+\mathrm{MA}$ to its first fork) shorter than wing width' might appear more useful. It must be emphasized here that the material from the Xiaheyan locality experienced plastic deformation, which could jeopardize the relevance of this character formulation. However, even if it is postulated that the specimen CNU-NX1-400 was affected by an elongation of factor 1.2 applied along its width, the corrected width would be about $28.8 \mathrm{~mm}$, against an unchanged $24.7 \mathrm{~mm}$ long RP stem. To our knowledge the newly formulated character is shared by Sh. qilianshansensis and readi only [according to Carpenter (1939, p. 39) an (unfortunately) undescribed forewing of readi possesses a very basal RP1/2 / RP3/4 fork, as in the known hind wing of the species]. Therefore we propose to assign the species readi to the genus Shenzhousia, as it exhibits its unique diagnostic trait.

\section{Shenzhousia qilianshanensis Zhang \& Hong, 2006 in Zhang et al. (2006)}

Figure 1

Material. Holotype specimen GMC97X101, and specimens GMC04X001, GMC04X002, CNU-NX1-401 (Fig. 1A), CNU-NX1-400 (Fig. 1B); and additional specimens CNU-NX1-402 (portion of mid part), CNU-NX1-403 (small portion of distal area), CNU-NX1-404 (portion of anal area), CNU-NX1-405 (small portion of mid part).

Commented diagnosis. The diagnosis of Sh. qilianshansensis must be reconsidered according to the assignment of readi to the same genus. Sh. qilianshansensis is slightly larger than $S h$. readi (ca. $35 \mathrm{~mm}$ wide, vs. 30-32 mm in the latter according to Carpenter (1939), but this is barely significant. More importantly $S h$. qilianshansensis also has wings with less cells overall. This difference is evident in the areas between MA and $\mathrm{MP}$, and MP and $\mathrm{CuA}$, and along the posterior wing margin [for $S h$. readi, see Carpenter (1933, fig. 1) and Carpenter (1939, fig. 7)]

General description. Estimated wing length about $160 \mathrm{~mm}$, width about $35 \mathrm{~mm}$; ScP distinct from wing margin, at least distal to the RP1/2 fork; RA straight and strong; occurrence of a strong oblique cross-vein in the area between RA and RP and opposite the RP1/ RP2 fork; stem of RP comparatively short; RP1 + 2 and RP3/4 delimiting a narrow area for a long distance; IR2 with posterior branches; RP3/4 slightly curved, parallel with main branch of MA; slightly undulated MA stronger than RP, with numerous posterior branches separated by intercalary veins; main stems of MA and MP parallel in basal part, strongly divergent distal to wing mid-length; MP simple; MP and anterior stem of $\mathrm{CuA}$ parallel, smoothly undulated in basal part; $\mathrm{CuA}$ and AA with numerous posterior branches separated by intercalary veins; basal stem of $\mathrm{CuP}$ short before its first fork; $\mathrm{CuP}$ with ca. 15 posterior branches (including putative intercalaries).

Descriptions. Specimen CNU-NX1-401 (Fig. 1A): fragment of right wing, positive imprint, preserved length $42.7 \mathrm{~mm}$, broadest width $23.1 \mathrm{~mm}$; RP + MA $3.3 \mathrm{~mm}$ long; stem of RP straight, $24.4 \mathrm{~mm}$ basal to the RP1/2/ $\mathrm{RP} 3 / 4$; two main posterior branches of $\mathrm{CuP}$ can be discerned in preserved part; basal stem of $\mathrm{CuP}$ before its first fork $14.6 \mathrm{~mm}$ long; AA with its base missing, preserved with eight long posterior branches. 


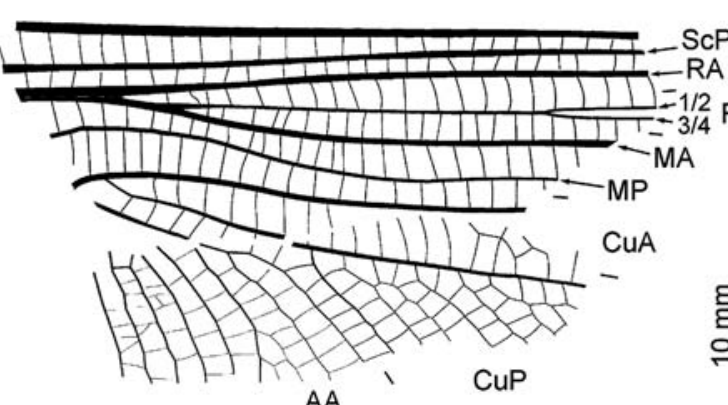

$A A$

CuP

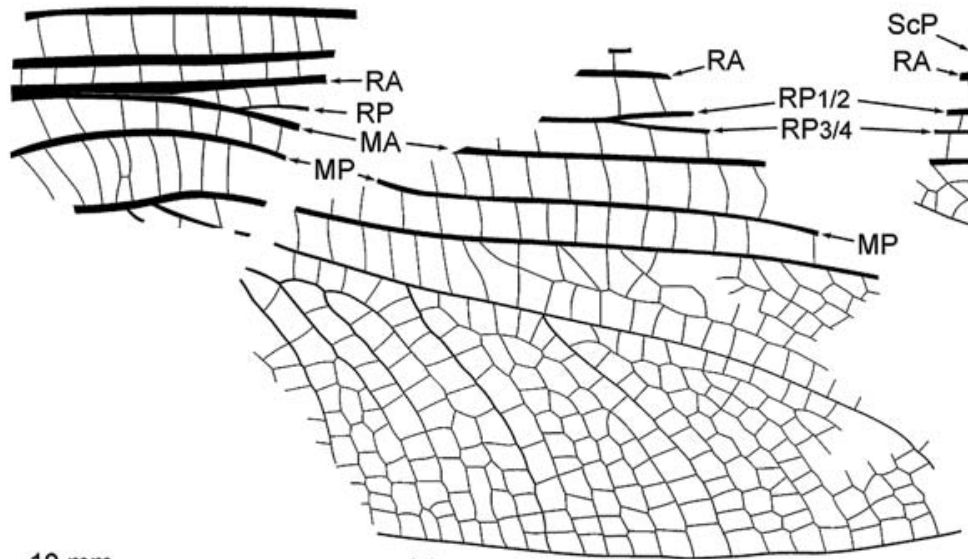

$\mathrm{ScP}$
A
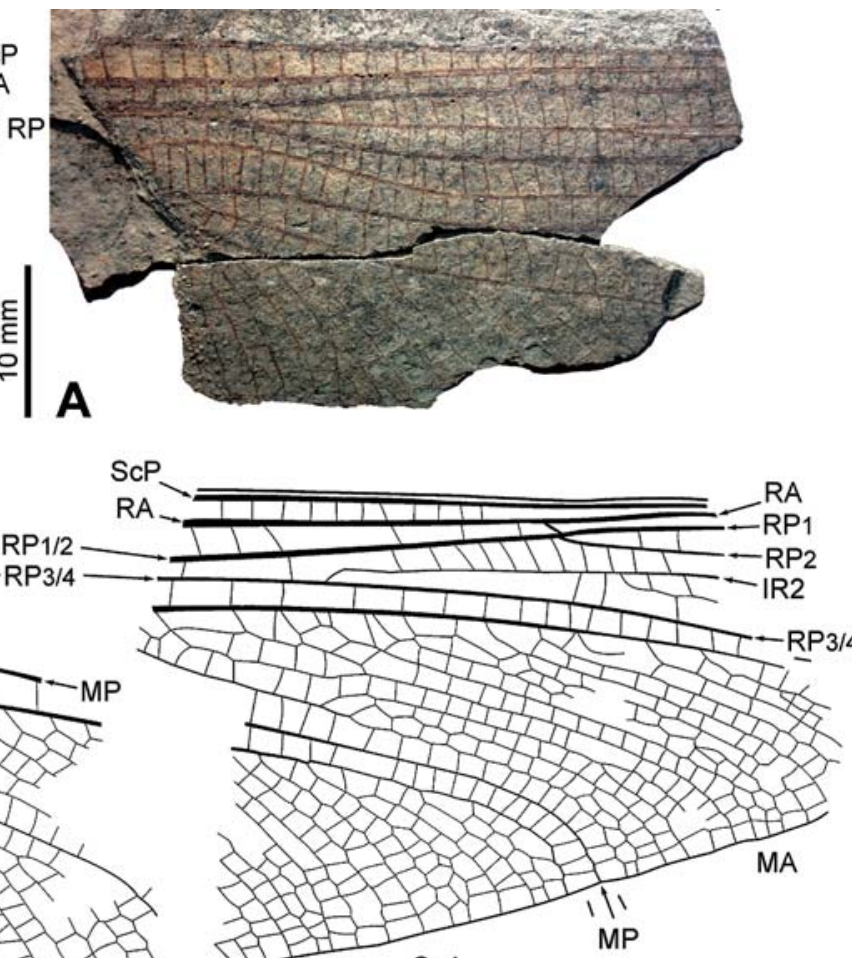

$10 \mathrm{~mm}$

AA

CuP

CuA

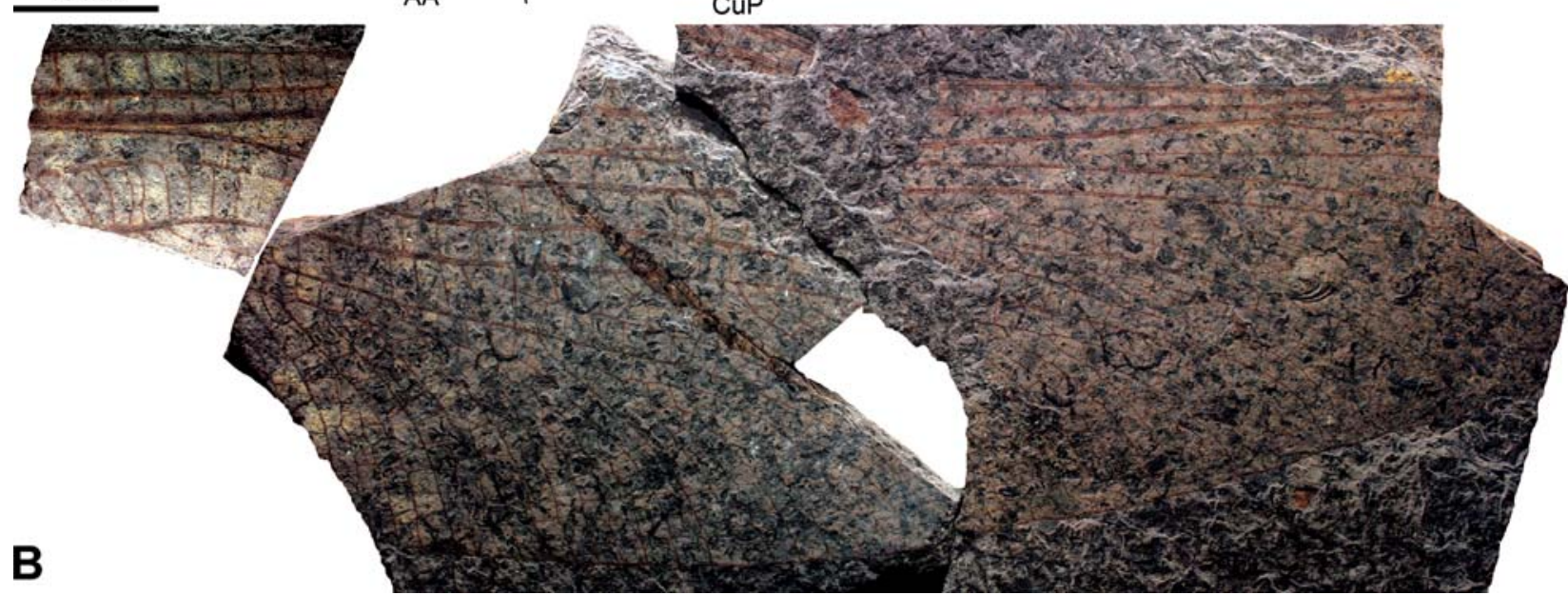

Figure 1. Shenzhousia qilianshanensis Zhang \& Hong, 2006 in Zhang et al. 2006; A. Specimen CNU-NX1-401, drawing and photograph (right wing, positive imprint); B. Specimen CNU-NX1-400, drawing and photograph (right wing, positive imprint).

Specimen CNU-NX1-400 (Fig. 1B): moderately well preserved isolated right wing, positive imprint, wing apex, base and anal area missing, specimen composed of several fragments; preserved wing length $105.0 \mathrm{~mm}$, broadest width $34.5 \mathrm{~mm}$; ScP gradually approaching anterior wing margin but keep distinct from it, at least distal to the RP1/RP2 fork; RA simple in preserved parts; occurrence of a strong oblique cross-vein in the area between RA and RP and opposite the RP1/RP2 fork; RP + MA $4.2 \mathrm{~mm}$ long; stem of RP (from its origin from RP + MA to its first fork) $24.7 \mathrm{~mm}$ long; $\mathrm{RP} 1 / 2$ simple for $47.1 \mathrm{~mm}$ then forked into RP1 and RP2; RP3/4 simple in preserved part; IR2 well defined, straight (in preserved part), with one posterior stem; MP and anterior stem of $\mathrm{CuA}$ strongly bent towards posterior wing margin distally; anterior stem of $\mathrm{CuP}$ slightly bent; $\mathrm{CuP}$ apparently with three distinct posterior branches separated by intercalary systems; basal stem of $\mathrm{CuP}$ before its first fork $17.6 \mathrm{~mm}$ long; stem of AA missing but its base can be discerned, AA preserved with four main posterior branches, forming a relatively broad anal area.

Discussion. According to their size and wing venation patterns, the specimens CNU-NX1-401 and CNU-NX1400 can be assigned to Sh. qilianshansensis. In particular they exhibit a comparatively short RP stem (from its origin from RP + MA to its first fork). This trait is uncommon among meganisopteran Odonatoptera (see above). In addition the new material and that described 
Zhang et al. (2006) were collected from the same locality. Undescribed specimens were assigned to Sh. qilianshansensis mostly based on their size.

\section{Oligotypus Carpenter, 1931}

1931 Oligotypus Carpenter, p. 106

2008 Sinomeganeura Ren et al. 2008, p. 225, n. syn.

Commented diagnosis. Our examination of the holotype of huangheensis [originally assigned to its own genus Sinomeganeura Ren et al. (2008)] revealed several substantial inaccuracies in the original description. Together with data on additional specimens, it entails a reconsideration of the diagnosis of the species provided by these authors (based on the holotype only), and of its taxonomic affinities.

The holotype specimen, which is comparatively poorly preserved (Fig. 2A), is provided with a stem of MP distinct from $\mathrm{Cu}$ for some distance (Fig. 2B), omitted in the drawing provided by Ren et al. (2008). We recognized distinct $\mathrm{CuA}-$ and $\mathrm{CuP}$-crossings in the basal part of the area between $\mathrm{MP}+\mathrm{Cu}$ and $\mathrm{AA}$ (Fig. 2B), as opposed to the single crossing identified by Ren et al. (2008; who considered this trait as diagnostic). The occurrence of distinct $\mathrm{CuP}-$ and $\mathrm{CuA}$ crossings in this species is confirmed by the specimens CNU-NX1-433 (Fig. 2C) and CNU-NX1-435 (Fig. 2E) (herein assigned to the species). Ren et al. (2008) state that the absence of narrowing of the area between MP and $\mathrm{CuA}$ is also diagnostic of huangheensis. However such narrowing does occur in the holotype (Fig. 2A) as well as in the specimen CNU-NX1-435 (Fig. 2E). Finally the character "first posterior branch of MA opposite base of RP3/4" is not present in the specimen CNUNX1-435 (Fig. 2E) and is therefore considered variable. In addition it is far from unique to huangheensis: it is present in Tupus permianus Sellards, 1906 (Carpenter 1939, fig. 6), Tupus gallicus Nel et al., 2009 (Nel et al. 2009, pl. 7 fig. 3; in which it varies between fore- and hind wings), several species of Arctopypus Nel et al., 2009 (Nel et al. 2009, pl. 9 fig. 6, pl. 10 fig. 5), and Curvitupus ariegensis $\mathrm{Nel}$ et al., 2009 (Nel et al. 2009, pl. 12 fig. 2), among others. Finally, note that Nel et al. (2009, p. 96) state that "ScA is distinctly shorter in the meganeurinae Sino. huangheensis Prokop et al., 2008 [Ren et al. 2008 instead], than in Meganeura monyi. Nevertheless, the 'subcostal' area of Sino. huangheensis is also rather broad and crossed by small cross-veins". We failed to observe these cross-veins.

As a result of our new observations, the taxonomic assignment of huangheensis must be reconsidered. This species differs from most meganisopteran Odonatoptera by its stem of $\mathrm{CuA}$ simple for a long distance (alternatively understood as 'stem of $\mathrm{CuA}$ longer than wing width', or ' $\mathrm{CuA}$ branched opposite or distal to its midlength'). This trait is present in Paralogus hispanicus $\mathrm{Nel}$ et al., 2009 (see original description) and Oligotypus tillyardi Carpenter, 1931 (Carpenter 1947, fig. 25), both members of the Paralogidae according to Nel et al. (2009; note that Paralogus aeschnoides has a shorter simple stem of CuA; see Carpenter 1960, text-fig. 2). Indeed the wing morphology of huangheensis fits with the diagnosis of the Paralogidae provided by Nel et al. (2009). Both huangheensis and O. tillyardi differ from Paralogus hispanicus after their stem of AA longer and provided with more numerous branches (possibly a plesiomorphy, however). Differences between huangheensis and $O$. tillyardi are very limited. Both have wings of similar widths (ca. 11-15 $\mathrm{mm}$ in the former, $11 \mathrm{~mm}$ in the latter), and very similar venation patterns. The only difference we noted is a fewer number of cells between $\mathrm{CuP}$ and the posterior wing margin, and the orientation of $\mathrm{CuP}$ branches, more oblique in O. tillyardi. Provided that these differences appear to be of minor importance, we propose to synonymize the monotypic genus Sinomeganeura, which huangheensis is the type-species, with Oligotypus. This option aims to avoid the maintaining of unnecessary monotypic taxa, which often obscure taxonomic information, without benefit.

Discussion. As outline above, membership to Oligotypus is primarily established based on the occurrence of a comparatively long CuA. Beckemeyer \& Engel (2011) described a specimen composed of the distal part of a wing, they assign to a new species (viz. tuscaloosae) within Oligotypus. However the available data does not allow the length of the simple section of $\mathrm{CuA}$ to be appreciated in this species. Therefore the generic assignment of tuscaloosae, and possible relationships to $O$. tillyardi and $O$. huangheensis, cannot be fully appreciated.

\section{Oligotypus huangheensis (Ren et al., 2008) n. comb.}

Figure 2

Material. Holotype specimen CNU-NX2006003 (Figs 2A-B), CNUNX1-433 (Figs 2C-D), CNU-NX1-435 (Fig. 2E), CNU-NX1-453 (Fig. 2F), CNU-NX1-407 (Fig. 2G); and additional specimens CNUNX1-431 (portion of costal area), CNU-NX1-432 (portion of basal half), CNU-NX1-434 (portion of base), CNU-NX1-436 (portion of base), CNU-NX1-455 (portion of base).

Commented diagnosis. Compared to O. tillyardi, wings with $\mathrm{CuP}$ branches less oblique, and area between $\mathrm{CuP}$ and posterior wing margin with fewer cells.

General description. Wings of medium size, estimated wing length about $89 \mathrm{~mm}$, width $11.0-14.0 \mathrm{~mm}$; precostal area short, ScA reaching anterior wing margin basal to the origin of $\mathrm{CuP}$ (from $\mathrm{MP}+\mathrm{Cu}$ ); ScP reaching anterior wing margin between the first fork of RP and the origin of IR2; RA simple and straight; occurrence of a particularly strong and oblique cross-vein between RA and RP, opposite the origin of RP2; IR1 and IR2 with many posterior branches (with putative intercalaries between them); MA only slightly bent, stronger than RP, with many posterior branches (with putative intercalaries between them); MP sometimes diverging from $\mathrm{MP}+\mathrm{Cu}$ for a short distance, then re-uniting 


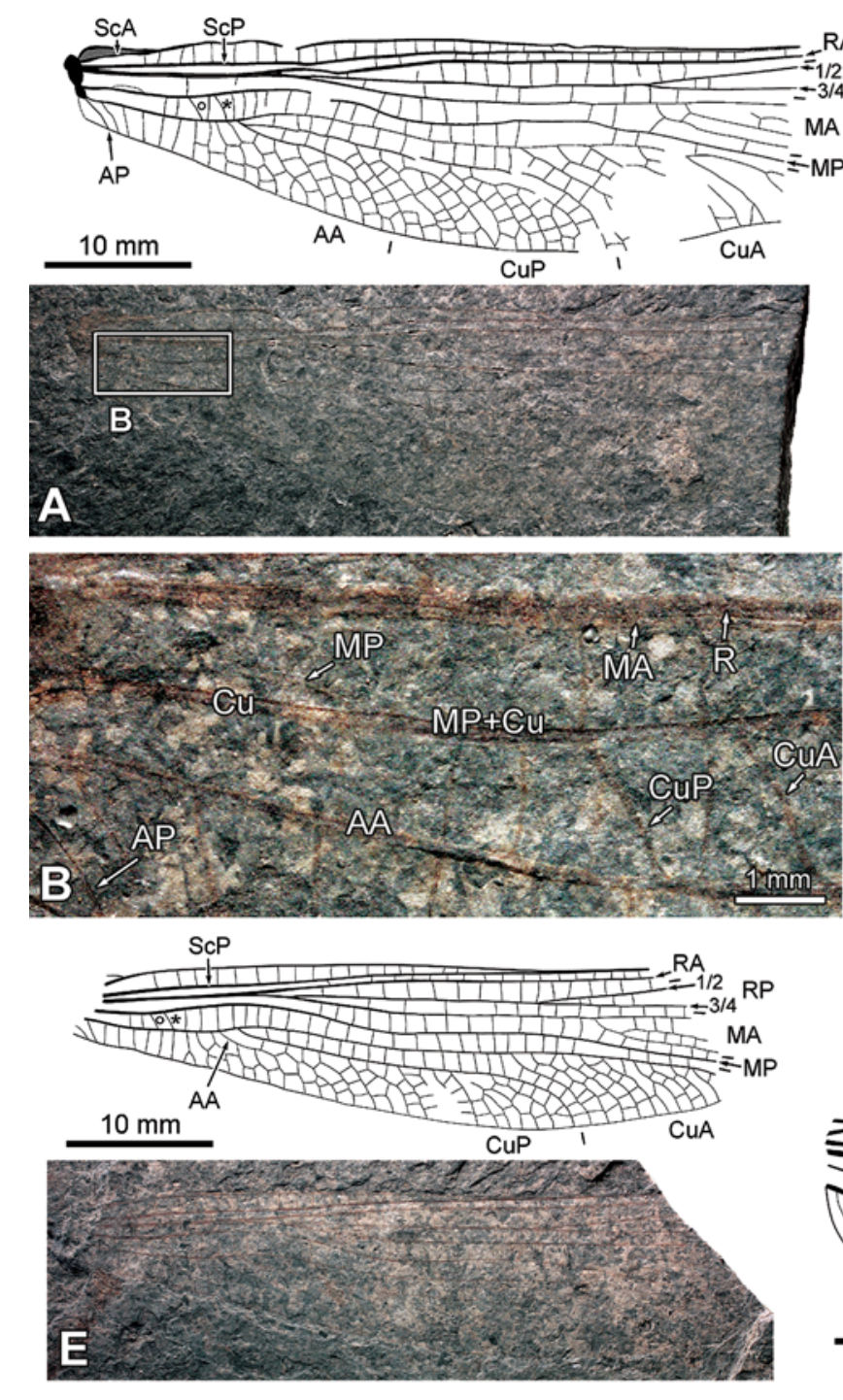

pe
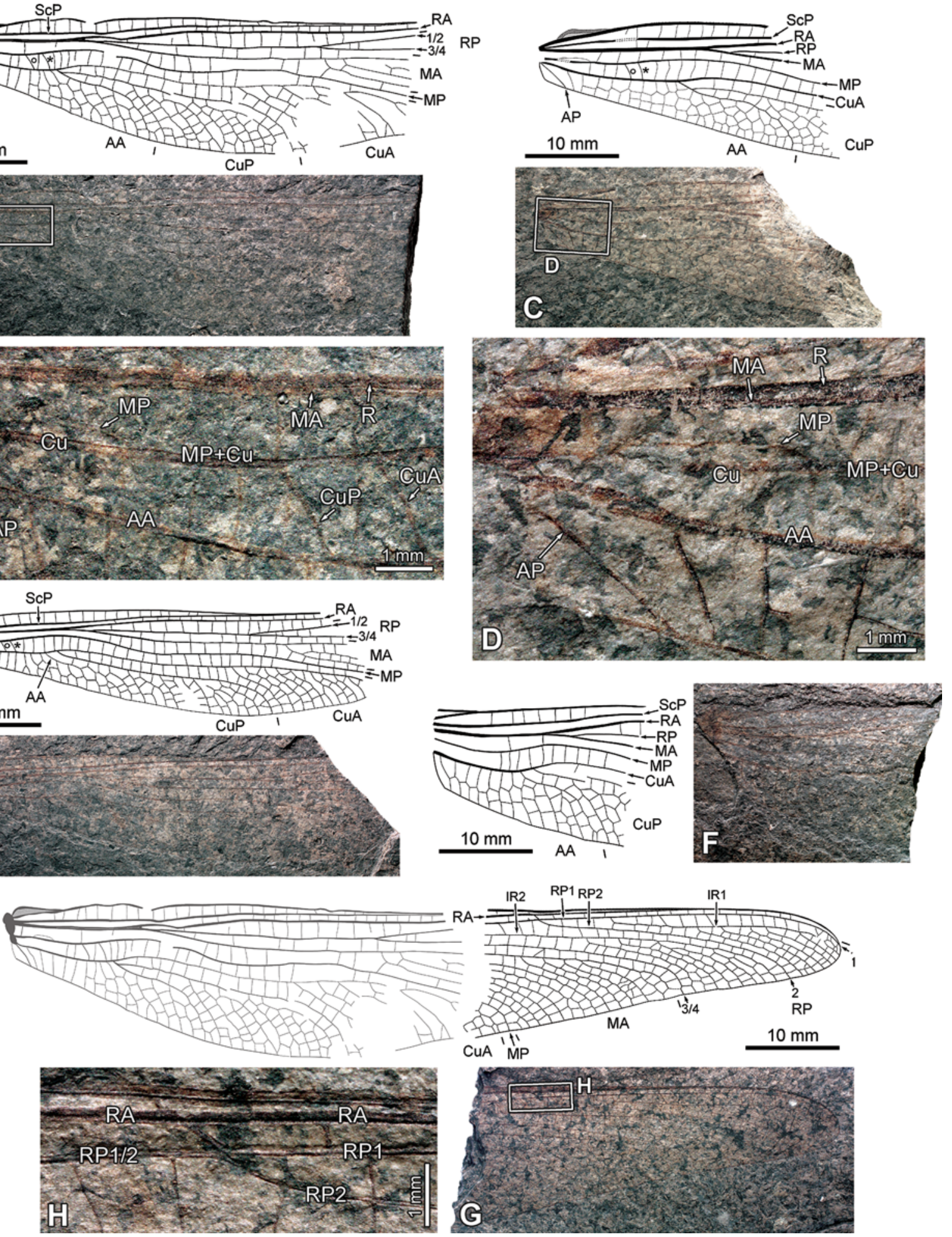

Figure 2. Oligotypus huangheensis (Ren et al. 2008) n. comb. ( ${ }^{*}$ and ${ }^{\circ}$ indicate the CuA- and CuP-crossings, respectively); A, B. Holotype specimen CNU-NX2006003; A. Drawing and photograph (right wing, positive imprint); B. Detail of wing base, as located on A; C, D. Specimen CNU-NX1-433; C. Drawing and photograph (left forewing, negative imprint); D. Detail of wing base, as located on C; E. Specimen CNU-NX1-435, drawing and photograph (right forewing, positive imprint); F. Specimen CNU-NX1-453, drawing and photograph (right hind wing, positive imprint); G, H. Specimen CNU-NX1-407; G. Drawing (with addition from specimen CNU-NX2006003, A, re-shaped; see text) and photograph (negative imprint, flipped horizontally); H. Detail of wing apex, as located on $\mathrm{G}$ (photograph under dry conditions only). 
with $\mathrm{Cu}$; MP moderately undulated, simple; CuP- and $\mathrm{CuA}$-crossings distinct and oblique; distal part of $\mathrm{CuA}$ only weakly undulated, with many posterior branches (with putative intercalaries between them); $\mathrm{CuP}$ and AA sometimes originating from $\mathrm{CuA}+\mathrm{CuP}+\mathrm{AA}$ fused; main stem of $\mathrm{CuP}$ basally parallel to posterior margin, bent towards posterior wing margin opposite the first fork of $\mathrm{CuA}$, with many posterior branches (and putative intercalaries between them); width of area between $\mathrm{CuP}$ and posterior wing margin rather broad; main stem of AA short, zigzagged, with several posterior branches; AP simple and short, reaching posterior wing margin near wing base.

Descriptions. Holotype specimen CNU-NX2006003 (Figs 2A-B): moderately well preserved right forewing with apex missing, negative and positive imprints, preserved length $49.0 \mathrm{~mm}$, maximum width $14.0 \mathrm{~mm}$; area between anterior wing margin and ScA darker, without cross-veins; actual end of ScP difficult to appreciate, about $10 \mathrm{~mm}$ distal of the RP1/2 / RP3/4 fork; stem of radial veins $13.6 \mathrm{~mm}$ long; $\mathrm{RP}+\mathrm{MA} 1.9 \mathrm{~mm}$ long; stem of RP $23.2 \mathrm{~mm}$ long basal to the RP1/2/RP3/4 fork; first branch of MA opposite the fork of RP1/2 / RP3/4; occurrence of weak vein diverging from $\mathrm{MP}+\mathrm{Cu}$ and re-uniting to it shortly after its origin (interpreted as MP; Fig. 2B); CuA-crossing two cells distal of CuP-crossing; first fork of $\mathrm{CuA} 19.4 \mathrm{~mm}$ distal to its origin from $\mathrm{CuA}+\mathrm{CuP} ; \mathrm{CuA}$ with several branches (and putative intercalaries between them); $\mathrm{CuP}$ and $\mathrm{AA}$ originating fused from $\mathrm{CuA}+\mathrm{CuP}+\mathrm{AA}$, separating $0.6 \mathrm{~mm}$ distal to their common origin; basal part of $\mathrm{CuP} 7.7 \mathrm{~mm}$ long basal to its first fork; $\mathrm{CuP}$ with more than eight main posterior branches (including putative intercalaries); AA with 6 posterior branches (including putative intercalaries); area between $\mathrm{AA}(+\mathrm{CuP}(+\mathrm{CuA}))$ and the posterior wing margin with a single row of cells

Specimen CNU-NX1-433 (Figs 2C-D): fragment of a moderately well preserved left forewing, negative imprint, preserved length $32.5 \mathrm{~mm}$, maximum width $12.8 \mathrm{~mm}$; stem of radial veins $17.8 \mathrm{~mm}$ long; $\mathrm{RP}+\mathrm{MA}$ $2.5 \mathrm{~mm}$ long; occurrence of weak vein diverging from $\mathrm{MP}+\mathrm{Cu}$ and re-uniting to it shortly after its origin (interpreted as MP; Fig. 2D); CuA- and CuP-crossings distinct, separated by a single cell; $\mathrm{CuP}$ and AA originating from $\mathrm{CuA}+\mathrm{CuP}+\mathrm{AA}$ as a single stem; $\mathrm{CuP}+\mathrm{AA} 1.6 \mathrm{~mm}$ long; $\mathrm{CuP} 8.1 \mathrm{~mm}$ long basal to its first fork; AA with 7 posterior branches (including putative intercalaries).

Specimen CNU-NX1-435 (Fig. 2E): a moderately well preserved right forewing with apex missing, positive imprint, slender, preserved length $43.7 \mathrm{~mm}$, maximum width $11.0 \mathrm{~mm}$; stem of radial veins $12.2 \mathrm{~mm}$ long; RP + MA $2.5 \mathrm{~mm}$ long; first posterior branch of MA $4.0 \mathrm{~mm}$ distal to the RP1/2 / RP3/4 fork; stem of RP $16.8 \mathrm{~mm}$ long before the RP1/2 / RP3/4 fork; $\mathrm{CuA}$ and $\mathrm{CuP}$-crossings distinct, separated by a single cell; $\mathrm{CuA}$ pectinated with more than 10 posterior branches (including putative intercalaries); $\mathrm{CuP}$ and $\mathrm{AA}$ originating from $\mathrm{CuA}+\mathrm{CuP}+\mathrm{AA}$ as distinct stems; $\mathrm{CuP}$ $7.9 \mathrm{~mm}$ long before its first fork; $\mathrm{CuP}$ with about nine main posterior branches (including putative intercalaries); main stem of AA relatively short and weakly developed, with few indistinct and short posterior branches, forming a relatively small anal area.

Specimen CNU-NX1-453 (Fig. 2F): fragment of a moderately well preserved right wing, probably a hind wing, positive and negative imprints, preserved length $23.0 \mathrm{~mm}$, maximum width about $15 \mathrm{~mm}$; stem of radial veins $12.1 \mathrm{~mm}$ long; $\mathrm{RP}+\mathrm{MA} 2.8 \mathrm{~mm}$ long; $\mathrm{CuP}$ about $4 \mathrm{~mm}$ long before its first fork; main stem of AA with 5 relatively long posterior branches, forming a relatively broad anal area; area between AA $(+\mathrm{CuP}$ $(+\mathrm{CuA}))$ and the posterior wing margin with two rows of cells.

Specimen CNU-NX1-407 (Figs 2G-H): fragment of a well preserved left forewing apex, negative imprint, preserved length $38.7 \mathrm{~mm}$, maximum width $13.3 \mathrm{~mm}$; RA strong, reaching anterior wing margin opposite the end of RP3/4; occurrence of a particularly strong crossvein between RA and RP, opposite the origin of RP2; base of IR1 about $7.7 \mathrm{~mm}$ distal of the base of RP2; area between RP1 and main stem of IR1 with one row of big cells; IR1 basally zigzagged, with 6 branches reaching apex and posterior margin; RP2 simple and smoothly curved; base of IR2 not preserved; IR2 $17.0 \mathrm{~mm}$ long basal to its first fork, with 7 posterior branches (including putative intercalaries); main stem of IR2 closely parallel with RP2; RP3/4 simple, strongly bent towards posterior margin near its end; main stem of MA closely parallel with RP3/4, with many branches (and putative intercalaries); location MP inferred based on the strong curve of the corresponding vein near the margin (typical of MP in related species).

Discussion. There are some differences between specimens we assign to $O$. huangheensis. In the first place the specimens CNU-NX2006003 (Figs 2A-B), CNUNX1-433 (Figs 2C-D), CNU-NX1-435 (Fig. 2E), and CNU-NX1-453 (Fig. 2F), preserving a similar area, differ in width. However, as mentioned above, the material from the Xiaheyan locality experienced plastic deformation. Assuming that deformation was due to an elongation of factor 1.2, correction applied to shape and size of the three former specimens would render the observed differences negligible. A more significant correction would be needed to reconcile the widths of specimens CNU-NX1-435 and CNU-NX1-453. However we assume that the latter is a fragment of a hind wing, known to commonly exceed forewing width in Odonatoptera. Other observed differences regard the occurrence of a cross-vein between the $\mathrm{CuA}$ - and CuP-crossings (or its lack thereof), of a portion of MP diverging from $\mathrm{MP}+\mathrm{Cu}$ for a short distance (or its lack thereof), and the occurrence of a short common stem $\mathrm{AA}+\mathrm{CuP}$ (or its lack thereof). It has never been demonstrated that these differences could be species-relevant. There- 
fore we propose to take a conservative stand and assume that they reflect intra-specific variation.

Assignment of the specimen CNU-NX1-407 (Fig. 2G) is less evident. None of the supposed $O$. huangheensis specimens exhibit the wing apex, and the specimen CNU-NX1-407 preserves mostly this portion only. The drawing of the holotype specimen (Fig. 2A) was deformed in an attempt to find a match with the specimen CNU-NX1-407. A widening of $112 \%$, compatible with plausible deformation endured by the fossil material, and sexual dimorphism (known to cover such a difference in extant Odonatoptera; see below), produced a good match to the specimen CNUNX1-407. In addition, the specimen cannot be attributed to any other species from the locality. The species orientalis (see below) is the one mostly similar to O. huangheensis. However, as delimited, and among other aspects, both species differ in the density of cells, in particular along the posterior wing margin. In the specimen CNU-NX1-407 12 cells cover the area between RP3/4 and MP along the posterior wing margin (which is $19.0 \mathrm{~mm}$ long, hence a density 0.63 cells per mm). Based on the specimens CNU-NX1-406 (Fig. 4B) and 408 (Fig. 4C), belonging to orientalis, similar measurements provide a density of 1.03 , and of about 1.1, respectively. Therefore we assume that the specimen CNU-NX1-407 belongs to O. huangheensis.

Undescribed specimens were assigned to O. huangheensis based on their size and aspects of wing venation. The specimen CNU-NX1-429, preserving a fragment of apical area, is only tentatively assigned to this species (an alternative option would be an assignment to orientalis).

\section{Tupus Sellards, 1906}

1906 Tupus Sellards, p. 249

2012 Paragilsonia Zhang, Hong \& Sun, 2012 in Su et al. (2012), p. 6; n. syn.

Discussion. Based on additional specimens, we propose to discuss the placement for orientalis, assigned by $\mathrm{Su}$ et al. (2012) to the monotypic genus Paragilsonia Zhang, Hong \& Sun, 2012 in Su et al. (2012), within meganisopteran Odonatoptera. Although deficient in some respect, the familial classification provided by Nel et al. (2009) will be followed initially to narrow down the options. Assignment to Namurotypidae can be excluded owing to the branched CuP (simple in the family; Bechly et al. 2001; Brauckmann \& Zessin 1989). Assignment to the Paralogidae can be excluded owing to the comparatively long ScP (reaching the margin between the RP1/2 / RP3/4 fork and the origin of IR2 in the family; Carpenter 1960). Assignment to the Kohlwaldiidae can be excluded owing to the distal parts of $\mathrm{CuP}$ and AA well developed, with numerous branches (reduced in the family; Nel et al. 2009). We are left with subfamilies assigned to the Meganeuridae by Nel et al. (2009). According to these authors the comparatively short ScA excludes an assignment to the Meganeurinae. In addition most Meganeurinae have a fused $\mathrm{CuP}$ - and $\mathrm{CuA}$-crossings, and this is not the case in our material (as discussed below, the occurrence of the distal oblique cross-vein, or its lack thereof, is considered inconclusive). The Piesbergtupinae are documented based on a single and fragmentary forewing (Zessin 2006), distinctive by the very narrow area between AA and the posterior wing margin (Nel et al. 2009). This is not the case of our specimens. The only remaining option is an assignment to the Tupinae.

According to Nel et al. (2009) this subfamily is distinctive after its strongly convex anterior margin delimiting the area anterior to ScA, which is devoid of cross-veins. However, these traits are not evident in the species described by these authors. Gilsonia titana Meunier, 1908, "which probably belongs to the Tupinae" [the corresponding genus is even synonymized with Tupus Sellards, 1906 by Carpenter (1992)], has a straight anterior wing margin and cross-veins in the corresponding area ( $\mathrm{Nel}$ et al. 2009, pl. 5, fig. 3). T. gallicus (Nel et al. 2009, pl. 7, fig. 3), among others, has a straight anterior wing margin, which is also the case in our material.

Indeed the Tupinae might be a rag-bag of meganisopteran Odonatoptera, as exemplified by the diagnosis of its type genus provided by Nel et al. (2009). According to these authors, the genus Tupus is characterized by (1) oblique and distinct $\mathrm{CuP}-$ and $\mathrm{CuA}-$ crossings, (2) "AA with numerous branches", (3) "CuP with more than three concave branches", (4) "MP with a double curve", and (5) "fore- and hind wing of very similar shape, with hind wing cubito-anal area only slightly broader than that of forewing".

The character (1) is known in the cousin relatives of the meganisopteran Odonatoptera, namely the Geroptera (Riek \& Kukalová-Peck 1984), and is therefore a plesiomorphy, probably at the level of Odonatoptera. In any case Nel et al. (2009) list this character as diagnostic of the Tupinae genus Arctotypus Martynov, 1932 as well. According to Nel et al. (2009) the "AA well-developed" is also diagnostic of the Paralogidae. How this formulation differs from that of character (2) is not evident (indeed Paralogus aeschnoides has numerous AA branches; Carpenter 1960, text-fig. 2). As formulated, the characters (3) and (4) are not unique to the genus Tupus (and the Tupinae), as they occurs in Paralogidae (Carpenter 1960, text-fig. 2) and Meganeurinae (e.g. in Meganeuropsis Carpenter, 1939; Carpenter 1947, fig. 22). Finally, the character (5) is possibly diagnostic for the whole Odonatoptera, and applies to many Palaeodictyoptera as well (among others, see Carpenter 1992).

Provided this situation we propose to employ the genus Tupus as a rag-bag, and assign orientalis (and our new material) to it. In any case the application of the determination key provided by Nel et al. (2009, pp. 118, 119) leads to this result. At this step it is necessary to discuss the relevance of the monotypic genus Paragilsonia, to which $\mathrm{Su}$ et al. (2012) proposed to as- 
sign orientalis. These authors list the following diagnostic characters: (1) "ScA short, precostal are without cross-veins", (2) "ScP long", (3) "Cu and MP separate at the base formed a 'cross-arch' before the equal distance fusion", (4) "brace of $\mathrm{CuA}$ and $\mathrm{CuP}$ oblique and separated", (5) "presence of crossvein between braces CuA and CuP", (6) "AA distinct, with about six posterior branches", (7) "anal area narrow", and (8) "AP short". However characters (1), (3), (7) and (8) are of minor importance, because they are present in many other meganisopteran Odonatoptera [as for character (1), see Figs 2A, C, F; as for character (3), see Figs 2A, $\mathrm{C}$; as for character (7), see Figs $2 \mathrm{~A}, \mathrm{C}, \mathrm{E}, 5 \mathrm{~A}, \mathrm{D}, \mathrm{E}$, 7A, B, 8; as for character (8), see Figs 2A, C, 5G; and, among others, see Nel et al. (2009)]. In addition, according to our species delimitation of $O$. huangheensis, the character (3) is variable in this species. Regarding character (2), it was appreciated by $\mathrm{Su}$ et al. (2012) based on an incomplete specimen. The new material indicates that $\mathrm{ScP}$ is not particularly longer than in many other meganisopteran Odonatoptera. The character (4) is of limited relevance, because it is not only very common among meganisopteran Odonatoptera (see Figs 2A, C, E, 5A, E, G; and, among others, see Nel et al. 2009), but also is a plesiomorphy at the level of Odonatoptera, as it occurs in Geroptera (see above). The character (5) has already been reported to occur in T. permianus (see Carpenter 1939) and Stephanotypus schneideri Zessin, 1983 (see original description), and its occurrence is variable in O. huangheensis (compare Figs 2A and E; see above). The character (6) is not particularly relevant either, as it occurs in various griffenfly genera such as Paralogus (see Carpenter 1960), and T. permianus (ibid.). Finally it appears unjustified to maintain the monotypic genus Paragilsonia.

\section{Tupus orientalis (Zhang, Hong \& Su, 2012 in Su et al. (2012)) n. comb.}

Figures 3-4

Commented diagnosis. Assuming an assignment of orientalis to the genus Tupus, the species is to be compared to other known species assigned to this taxon [as listed by Nel et al. (2009), excluding readi, assigned to Shenzhousia above; notice that Carpenter (1992) gives a broader sense to this taxon]. In T. permianus [(see original description and revision in Carpenter (1939)], Tupus gracilis Carpenter, 1947 (see original description, fig. 24, and pl. 1, fig. 1), and T. gallicus (see original description, pl. 7, fig. 3) the stem of RP + MA is particularly short, in both fore- and hind wings, unlike in T. orientalis.

In T. whitei Carpenter, $1928 \mathrm{CuA}$ forks very basally, unlike in T. orientalis. The species T. gilmorei Carpenter, 1927 is so poorly documented (viz. based on an incomplete and very poorly preserved forewing) that we consider it as meganisopteran Odonatoptera incertae se- dis. As a result it appears justified to maintain the species T. orientalis.

Note that the new species is slightly larger than T. permianus, said to range between 90 and $100 \mathrm{~mm}$ by Carpenter (1931). However this measurement, based on the holotype (assumed to be lost by Carpenter 1939), might have been based solely on the indication "slightly reduced" applying to fig. 1 in Sellards (1906), and is therefore subject to caution. Indeed a specimen composed of authentic fragments assembled in plaster (incorporating hand-carved missing parts) and which is very likely the holotype was recovered by $\mathrm{C}$. Durden (Texas Memorial Museum, Austin, TX, USA; R. Beckemeyer, pers. com., 2011). Based on a photograph of this specimen provided by R. Beckemeyer, wing length ranges between 110 and $120 \mathrm{~mm}$. According to the magnification indicated for the figure $38.4 \mathrm{~b}$ in Carpenter (1992) [erroneously indicated as reproduced from Carpenter (1931)], the specimen represented on fig. 6 in Carpenter (1939) was about $104 \mathrm{~mm}$ long if it were complete. As currently documented differences in the size ranges of T. orientalis and T. permianus do exist but are not substantial, owing to the intra-specific size variation observed in extant Odonatoptera (see below). The species $T$. whitei is significantly smaller than T. orientalis (93 mm vs. $112-140 \mathrm{~mm}$ ).

General description. Forewing: estimated wing length about $112-140 \mathrm{~mm}$, width about $19-25 \mathrm{~mm}$; precostal area short, ScA reaching anterior wing margin slightly basal to the origin of $\mathrm{CuP}$ (from $\mathrm{MP}+\mathrm{Cu}$ ); ScP long and straight, reaching anterior wing margin between the origin of IR2 and fork of RP1/2; RA simple and straight, reaching anterior wing margin distal to the first fork of IR1; occurrence of a particularly strong and oblique cross-vein between RA and RP, near the $\mathrm{RP} 1 / 2$ fork; area between RP1/2 and RP3/4 narrow for a long distance; IR1 and IR2 with many posterior branches (with putative intercalaries between them); IR2 basally zigzagged; main stem of IR1 straight, parallel with RP1, with one row of elongated cells between them (rarely two rows); RP2 simple and slightly curved, closely parallel with main stem of IR2; MA only slightly bent distal to its origin, stronger than RP, with many posterior branches (with putative intercalaries between them); MP occasionally diverging from $\mathrm{MP}+\mathrm{Cu}$ for a short distance, then re-uniting with $\mathrm{Cu}$; MP simple, strongly undulated basally; distal to the stem of $\mathrm{RP}+\mathrm{MA}$, area between MP and $\mathrm{CuA}$ narrow; $\mathrm{CuP}$ and then $\mathrm{CuA}$ successively diverging from $\mathrm{MP}+\mathrm{Cu}$, and $\mathrm{MP}+\mathrm{CuA}$, respectively, forming oblique stems between $\mathrm{MP}+\mathrm{Cu} / \mathrm{MP}+\mathrm{CuA} / \mathrm{MP}$ and $\mathrm{AA} / \mathrm{AA}+\mathrm{CuP} /$ $\mathrm{AA}+\mathrm{CuA}+\mathrm{CuP}$; or sometimes, stems of $\mathrm{CuP}$ and $\mathrm{CuA}$ fused into a single oblique $\mathrm{CuP}+\mathrm{CuA}$ crossing; distal part of CuA weakly undulated, with many posterior branches (with putative intercalaries between them); $\mathrm{RP} 3 / 4, \mathrm{MA}, \mathrm{MP}, \mathrm{CuA}$ and $\mathrm{CuP}$ bent posteriorly near the posterior wing margin; main stem of $\mathrm{CuP}$ parallel to posterior wing margin in its basal half, bent towards 

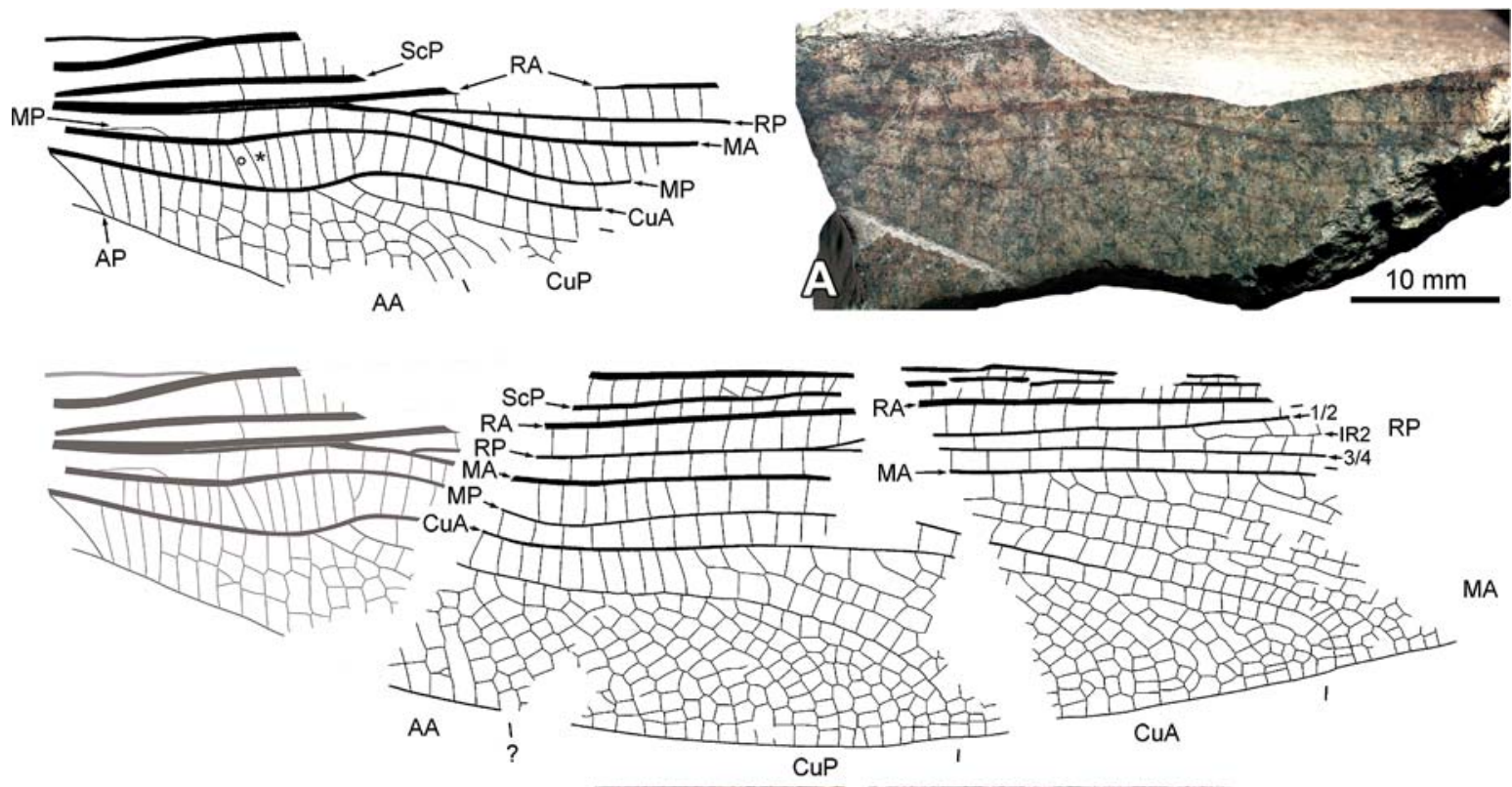

MA

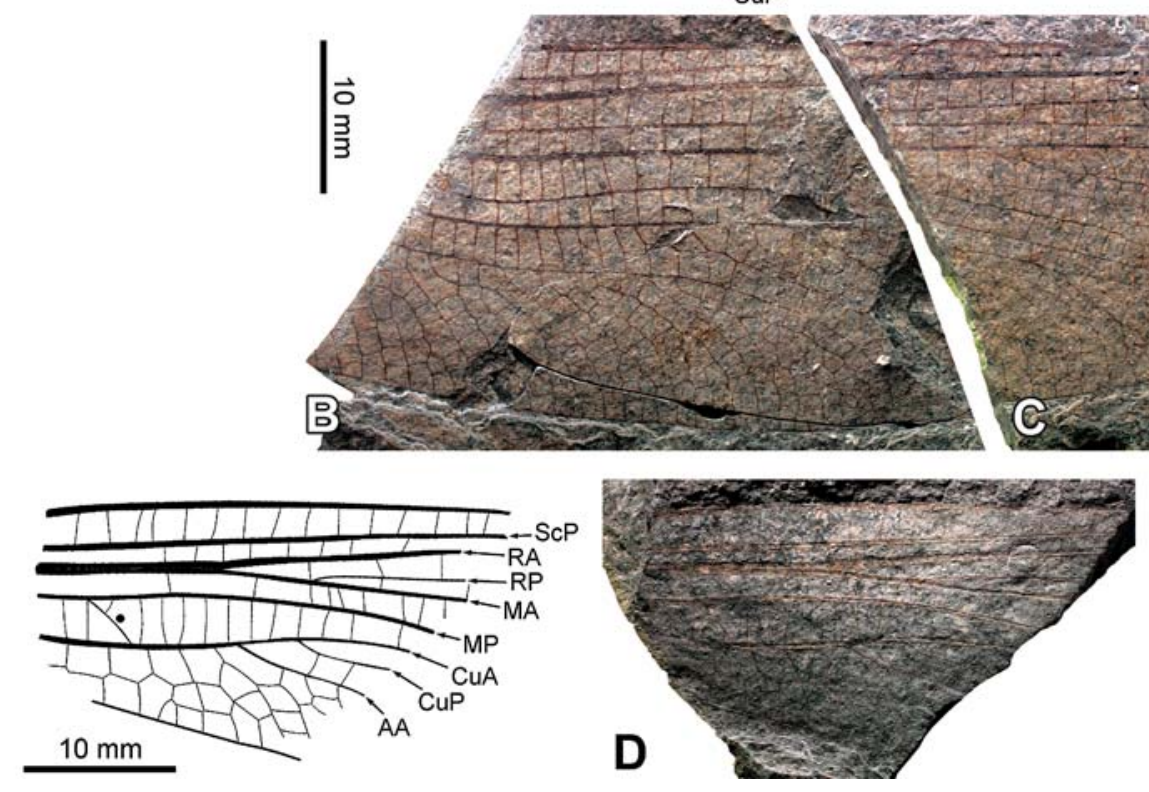

Figure 3. Tupus orientalis (Zhang, Hong \& Su, 2012 in Su et al. 2012) n. comb.; A. Specimen CNU-NX1-410, drawing and photograph (right forewing, negative imprint, flipped horizontally); B. Specimen CNU-NX1-413, drawing (with addition from specimen CNU-NX1-410, A., re-shaped; see text) and photograph (right wing, positive imprint); C. Specimen CNU-NX1-457, drawing and photograph (right wing, positive imprint); D. Specimen CNU-NX1-409, drawing (• indicates the common CuA- and CuP-crossing) and photograph (left wing, negative imprint).

posterior wing margin opposite the first fork of $\mathrm{CuA}$, with many posterior branches (and putative intercalaries between them); basal part of $\mathrm{CuP}$ before its first fork short; main stem of AA very short, with many posterior branches; cells density along posterior wing margin high (at least 1 cell per mm between ends of RP3/4 and MP).

Hind wing (based on a single fragment of wing base): similar to forewing, except for the area between $\mathrm{AA}(+\mathrm{CuP}(+\mathrm{CuA}))$ and the posterior wing margin, broad, with many long and zigzagged branches.

Descriptions. Specimen CNU-NX1-410 (Fig. 3A): fragment of right forewing base, negative imprint, pre- served length $45.7 \mathrm{~mm}$, stem of radial veins about $20 \mathrm{~mm}$ long; RP + MA $4.4 \mathrm{~mm}$ long; MP diverging from $\mathrm{MP}+\mathrm{Cu}$ for a short distance and then re-uniting with $\mathrm{Cu}$; $\mathrm{CuP}$ and then $\mathrm{CuA}$ successively diverging from $\mathrm{MP}+\mathrm{Cu}$, and $\mathrm{MP}+\mathrm{CuA}$, respectively, forming oblique crossings; $\mathrm{CuP}$ diverging from AA $((+\mathrm{CuP})+\mathrm{CuA})$ opposite the origin of the stem of $\mathrm{RP}+\mathrm{MA}$; basal part of CuP before its first fork about $5 \mathrm{~mm}$ long; AP well defined, simple and short, reaching posterior wing margin near wing base.

Specimen CNU-NX1-413 (Fig. 3B): fragment of right forewing, positive imprint, preserved length covering about $41.4 \mathrm{~mm}$, maximum width $25.3 \mathrm{~mm}$; first branch of $\mathrm{CuA} 8.4 \mathrm{~mm}$ basal of the first fork of RP; 


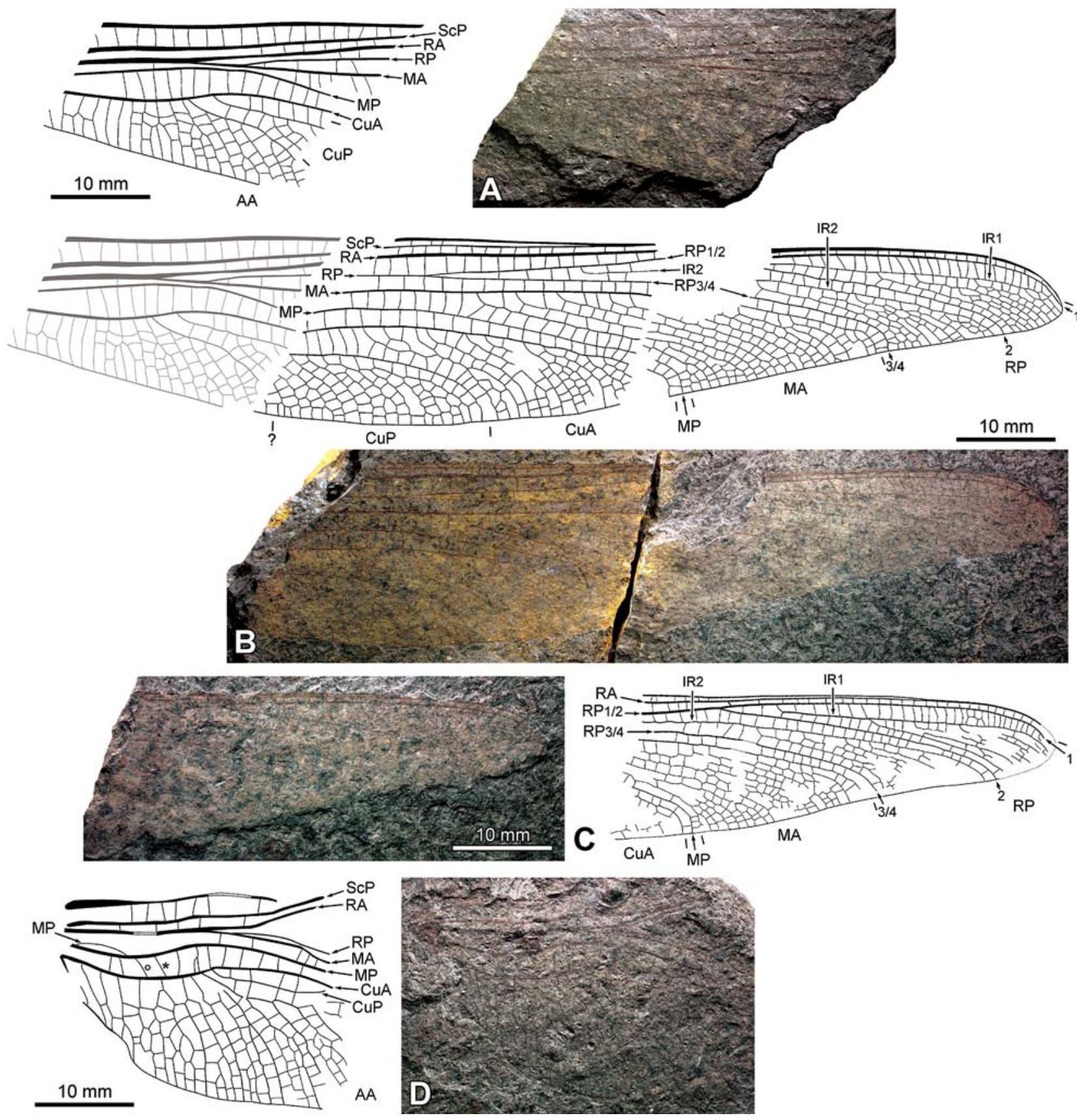

Figure 4. Tupus orientalis (Zhang, Hong \& Su, 2012 in Su et al. 2012) n. comb.; A. Specimen CNU-NX1-412, drawing and photograph (right forewing, negative imprint, flipped horizontally); B. Specimen CNU-NX1-406, drawing (with addition from specimen CNU-NX1-412, A., re-shaped, see text) and photograph (left forewing, positive imprint, flipped horizontally); C. Specimen CNU-NX1-408, drawing and photograph (left wing, negative imprint); D. Specimen CNU-NX1-411, drawing and photograph (left hind wing, positive imprint, flipped horizontally).

maximum width of area between $\mathrm{CuP}$ and posterior wing margin $9.5 \mathrm{~mm}$, with more than eleven rows of cells.

Specimen CNU-NX1-457 (Fig. 3C): fragment of right forewing, roughly corresponding to the distal third quarter, positive imprint, preserved length covering about $37 \mathrm{~mm}$, maximum width $23.3 \mathrm{~mm}$; ScP distinct from anterior wing margin in preserved part; area between RP1/2 and RP3/4 narrow for a long distance; $\mathrm{MA}$ and $\mathrm{CuA}$ with numerous branches (and putative in- tercalaries between them); MP simple, bent posteriorly near posterior wing margin.

Specimen CNU-NX1-409 (Fig. 3D): fragment of left forewing base, negative imprint, preserved length $31.2 \mathrm{~mm}$, estimated maximum width about $17 \mathrm{~mm}$; area between anterior wing margin and ScA missing; $\mathrm{RP}+\mathrm{MA} 5.9 \mathrm{~mm}$ long; stems of $\mathrm{CuP}$ and $\mathrm{CuA}$ fused into a single oblique crossing, with a cross-vein connected to it; AA with several short posterior branches, corresponding area narrow. 
Specimen CNU-NX1-412 (Fig. 4A): fragment of right forewing base, negative imprint, preserved length covering $38.2 \mathrm{~mm}$, preserved width $16.1 \mathrm{~mm}$; RP + MA $5.2 \mathrm{~mm}$ long; MP bent, very close to $\mathrm{R}+\mathrm{MA} /$ $\mathrm{RP}+\mathrm{MA}$, maybe as a result of compression of the original three-dimensional wing structure; basal part of $\mathrm{CuP}$ before its first fork about $6 \mathrm{~mm}$ long; AA with several posterior branches (and putative intercalaries between them); anal area broad, with at best six rows of cells between main stem of AA and posterior wing margin.

Specimen CNU-NX1-406 (Fig. 4B): a well preserved left wing (probably a forewing), basal first third missing, positive imprint composed of two fragments, preserved length covering $81.8 \mathrm{~mm}$, maximum width $18.8 \mathrm{~mm}$; area between RP1/2 and RP3/4 narrow for a long distance; RP1, RP2, RP3/4 and MP simple, posteriorly bent near posterior wing margin; IR1, IR2, MA, $\mathrm{CuA}$ and $\mathrm{CuP}$ with numerous branches (and presumed intercalaries between them); first branch of $\mathrm{CuA}$ $5.9 \mathrm{~mm}$ basal to first fork of RP; first branch of MA $5.4 \mathrm{~mm}$ distal to first fork of RP; IR2 originating $15.8 \mathrm{~mm}$ distal to first RP fork; base of RP1 and RP2 missing; widest part of the area between main stem of $\mathrm{CuP}$ and posterior wing margin $6.5 \mathrm{~mm}$ broad, with rows of 8 cells at best.

Specimen CNU-NX1-408 (Fig. 4C): fragment of left wing apex, negative imprint, preserved length $44.5 \mathrm{~mm}$, widest area $14.3 \mathrm{~mm}$; occurrence of particularly strong and oblique cross-vein between RA and RP, slightly distal to the origin of RP2; IR1 originating $5.6 \mathrm{~mm}$ distal to the RP1/2 fork; area between ends of RP3/4 and MP with numerous small cells.

Specimen CNU-NX1-411 (Fig. 4D): fragment of left hind wing base, main radial veins distorted (maybe as the result of a disruption of the wing), positive imprint, preserved length $28.8 \mathrm{~mm}$, widest area $21.3 \mathrm{~mm}$; stem of radial veins $14.9 \mathrm{~mm}$ long; RP + MA $2.4 \mathrm{~mm}$ long; $\mathrm{CuP}$ - and $\mathrm{CuA}-$-crossings distinct, oblique; $\mathrm{CuP}$ separating from $\mathrm{CuA}$ opposite the origin of $\mathrm{RP}+\mathrm{MA}$; $\mathrm{AA}$ with more than six long posterior branches (including putative intercalaries); anal area about $12 \mathrm{~mm}$ wide opposite the origin of AA.

Discussion. The maximum forewing size was estimated based on the assemblage presented on Figs 3B-C, augmented by the apical portion of the specimen CNUNX1-406 (Fig. 4B), rescaled to fit. The minimum forewing size was estimated based on the assemblage presented on Fig. 4B (with minor addition for the base from the specimen CNU-NX1-410, reproduced on Fig. $3 \mathrm{~A}$, rescaled). The ratio of 1.25 between the longest and the shortest wing is well consistent with specific identity. Among European and North African Odonata species, the ratio between the longest female hind wing and the shortest male hind wing is often about 1.3, and reaches 1.56 in Acisoma panorpoides ascalaphoides (Rambur, 1842), 1.60 in Trithemis annulata (Palisot de Beauvois, 1805-1821), 1.61 in Calopteryx haemorrhoidalis (Van der Linden, 1825), 1.69 in Dipla- codes lefebvrii (Rambur, 1842), and culminates in Coenagrion mercurial (Charpentier, 1840), with a ratio of 1.75 (data from d'Aguilar \& Dommanget 1998).

Specimens were assigned to a single species based on their match (such as CNU-NX1-410, 413, and 457; assembled on Figure 3A), and similarities in wing venation and cross-venation (such as specimens CNU-NX1406 and 408). The most fragmentary specimens were more problematic. The specimen CNU-NX1-409 was assigned to the same species as others mostly because it is too large to be assigned to O. huangheensis, and too small to be assigned to Sh. qilianshenensis. It differs from other specimens assigned to orientalis in which the base is preserved after its fused CuP- and CuA-crossings, a character elsewhere emphasized as potentially diagnostic at the sub-familial or familial levels (e.g. in Nel et al. 2009). Our decision is prompted by plausibility of variation of this character in some species (variation is needed at the species level for evolution to take place), and by the fact that apart from the $\mathrm{CuP}-$ and $\mathrm{CuA}$-crossings, the morphology of the specimen CNU-NX1-409 is consistent to that observed in other specimens. It appears parsimonious to assign it to the same species then. Undescribed specimens were assigned to the same species based on their size and aspects of wing venation.

As for assignment of our set of specimens to T. orientalis, the fact that the holotype of the species is very incomplete (composed of the basal third of a wing; Su et al. 2012) make the task uneasy. Yet we propose to assign the new material to this species because no major differences between the holotype and the new specimens were observed, and because the sizes are consistent. Notice that description and figures provided by $\mathrm{Su}$ et al. (2012) provide a wide range of width for the holotype (from $17.9 \mathrm{~mm}$ to $20.0 \mathrm{~mm}$ ). Our measurement of the specimen indicates a width of $19.4 \mathrm{~mm}$, which is compatible with the range observed in the new set of specimens. Other species from the same locality are either larger, or smaller.

\section{Erasipterella Brauckmann, 1983}

1983 Erasipterella Brauckmann, p. 9

2012 Sinierasiptera Zhang, Hong \& Su, 2012 in Su et al. (2012), p. 3; n. syn.

Commented diagnosis. Based new data on Erasipterella $j i n i$, and on the incomplete data on 'Erasipteridae'-like species (see below), it can be deduced that the absence of branches of CuP clearly distinct from the main stem of $\mathrm{AA}$ in forewings is a diagnostic character of the genus Erasipterella Brauckmann, 1983, as well as the comparatively distally located RP $1 / 2$ / RP $3 / 4$ fork. The new data also shows that a single antenodal cross-vein is present in fore- and hind wings (probably occurring in Erasipterella piesbergensis).

Discussion. Discussion on the position of this genus can be provided here, as it will assist to decipher the 
affinities of jini, to which we assign new specimens. According to Brauckmann \& Zessin (1989) the family Erasipteridae, erected by Carpenter (1939) to include Erasipteron larischi Pruvost, 1933, also includes Erasipterella piesbergensis Brauckmann, 1983, Erasipteroides valentini (Brauckmann et al., 1985), and Whalleyala bolsoveri (Whalley, 1979). The species Rasnitsynala sigambrorum Zessin et al., 2011 and Zessinella siope Brauckmann, 1988 are to be considered also.

The type species of the type genus of the family was investigated by Carpenter (1939) based on the photograph provided in Pruvost (1933). Later on Kukalová (1964) added an archaedictyon to the reconstruction. This reconstruction was followed and reproduced by Riek \& Kukalová-Peck (1984, fig. 4) and Brauckmann \& Zessin (1989, fig. 9), among others. However examination of the available photographs, and according to the original description, this archaedictyon merely corresponds to the surface of the rock matrix. The best reconstruction to date is that of Carpenter (1939). According to it, and to the original photograph, it is clear that the $\mathrm{CuA}$-crossing is located distal to the origin of $\mathrm{AA}$ (from $\mathrm{CuP}+\mathrm{AA}$ ). This condition occurs only in the most plesiotypic Odonatoptera, namely the Geroptera (Riek \& Kukalová-Peck 1984). The simple CuP is another similarity with this group. However, as stated by Riek \& Kukalová-Peck (1984), this species is more derived than representatives of the Geroptera, notably owing to its complete fusion of MA with R at the wing base.

Based on photographs of the holotype of Erasipterella piesbergensis (provided by K. L. Herd as pers. com. to OB, 2011; and see Brauckmann 1983, fig. 1), it can be ascertained that the available data is deficient to some extent (consider Brauckmann \& Zessin 1989, figs 11a, b; among others). No archaedictyon occurs between the usual cross-veins [and C. Brauckmann, pers. com. to OB, 2011; archaedictyon was omitted in Brauckmann \& Herd (2003)]. In the hind wing, AA reaches the posterior wing margin opposite the 5 th cell of the area between $\mathrm{CuA}$ and $\mathrm{CuP}$. As a consequence the area occupied by $\mathrm{CuP}$ is wider than previously appreciated, with $\mathrm{CuP}$ provided with 5 branches, instead of being simple. Examination of original and new photographs also reveals that in both fore- and hind wings the CuA-crossing is located opposite the origin of $\mathrm{AA}$ (from $\mathrm{CuP}+\mathrm{AA}$ then), and the CuP-crossing is located immediately basal to it. These traits, in particular the branched $\mathrm{CuP}$, and the more basal location of the $\mathrm{CuA}$-crossing, indicate closer relationships of this species with meganisopteran Odonatoptera than with Erasipteron larischi.

According to the original photographs of Erasipteroides valentini (Brauckmann et al. 1985, pl. 15) it is dubious that this species possesses an archaedictyon either (and see Bechly et al. 2001, figs 1, 7). In contrast to Erasipterella piesbergensis, AA seems to be very long (at least in hind wing, which are the best documented, with the basal half known). The CuA-crossing is located distal to the origin of $\mathrm{AA}$ (from $\mathrm{CuP}+\mathrm{AA}$ ) in both wings pairs (Bechly et al. 2001, figs 1, 7). According to Bechly et al. (2001, figs 1, 7; see also Grimaldi \& Engel 2005, fig. 6.28), CuP is most likely simple in both wing pairs, a trait shared with Geroptera and Erasipteron larischi (among others).

The accuracy of Whalley's (1979) reconstruction of the forewing of $W$. bolsoveri (followed by Brauckmann \& Zessin 1989, fig. 12; among others) is dubious: to our knowledge there is no known Odonatoptera to have a simple RP1/2, as represented by Whalley (1979). Other oddities in this reconstruction force us to consider this species as Odonatoptera incertae sedis until a proper revision is undertaken.

Zessin et al. (2011) assigned Rasnitsynala sigambrorum to the "Erasipteridae". The only available specimen is so incomplete that none of the decisive characters can be observed. We considered it as Odonatoptera incertae sedis.

Finally the species $Z$. siope is documented based on a single, fragmentary specimen, mostly preserving bases of right fore- and hind wings. The only preserved character relevant to the position of this species is the position of the fusion of MP with $\mathrm{Cu}$. It is, as a matter of fact, a fusion of MP with $\mathrm{CuA}$, as it occurs distal to the CuP-crossing. This trait is shared with Erasipteron larischi, but is absent in Erasipterella piesbergensis, in which MP fused with $\mathrm{Cu}$ at the wing base (presumably a derived condition).

In summary the 'Erasipteridae' is a group mostly composed of poorly described and/or poorly documented species, and which is most likely paraphyletic.

$\mathrm{Su}$ et al. (2012) described jini from the Xiaheyan locality and assigned it to its own genus Sinierasiptera Zhang, Hong \& Su, 2012 in Su et al. (2012) and family Sinierasipteridae Zhang, Hong \& Su, 2012 in Su et al. (2012). Based on abundant material described below, affinities of jini with Erasipterella piesbergensis are evident: both species are comparatively small (forewing width is about $7 \mathrm{~mm}$ in Erasipterella piesbergensis, about $9 \mathrm{~mm}$ in jini), with CuP branches not clearly distinct from AA (or, in other words, with cross-veins located between branches of CuP aligned with AA), especially in forewings. It appears unjustified to maintain a distinct genus for jini. It goes without saying that the family Sinierasipteridae and its diagnosis as provided by $\mathrm{Su}$ et al. (2012) are of limited interest, provided the deficient nature of data on 'Erasipteridae', and of basal Odonatoptera in general (and indeed, as for the diagnosis of the genus Paragilsonia, that of the family Sinierasipteridae is replete with characters shared by many other Odonatoptera).

\section{Erasipterella jini (Zhang, Hong \& Su, 2012 in Su et al. (2012)) n. comb.}

Figure 5

Material. Holotype specimen GMC07QNX003, and specimens CNUNX1-440 (Fig. 5F), CNU-NX1-441 (Fig. 5D), CNU-NX1-442 (Fig. 6), CNU-NX1-443 (Fig. 5A), CNU-NX1-444 (Figs 5B-C), CNU-NX1- 


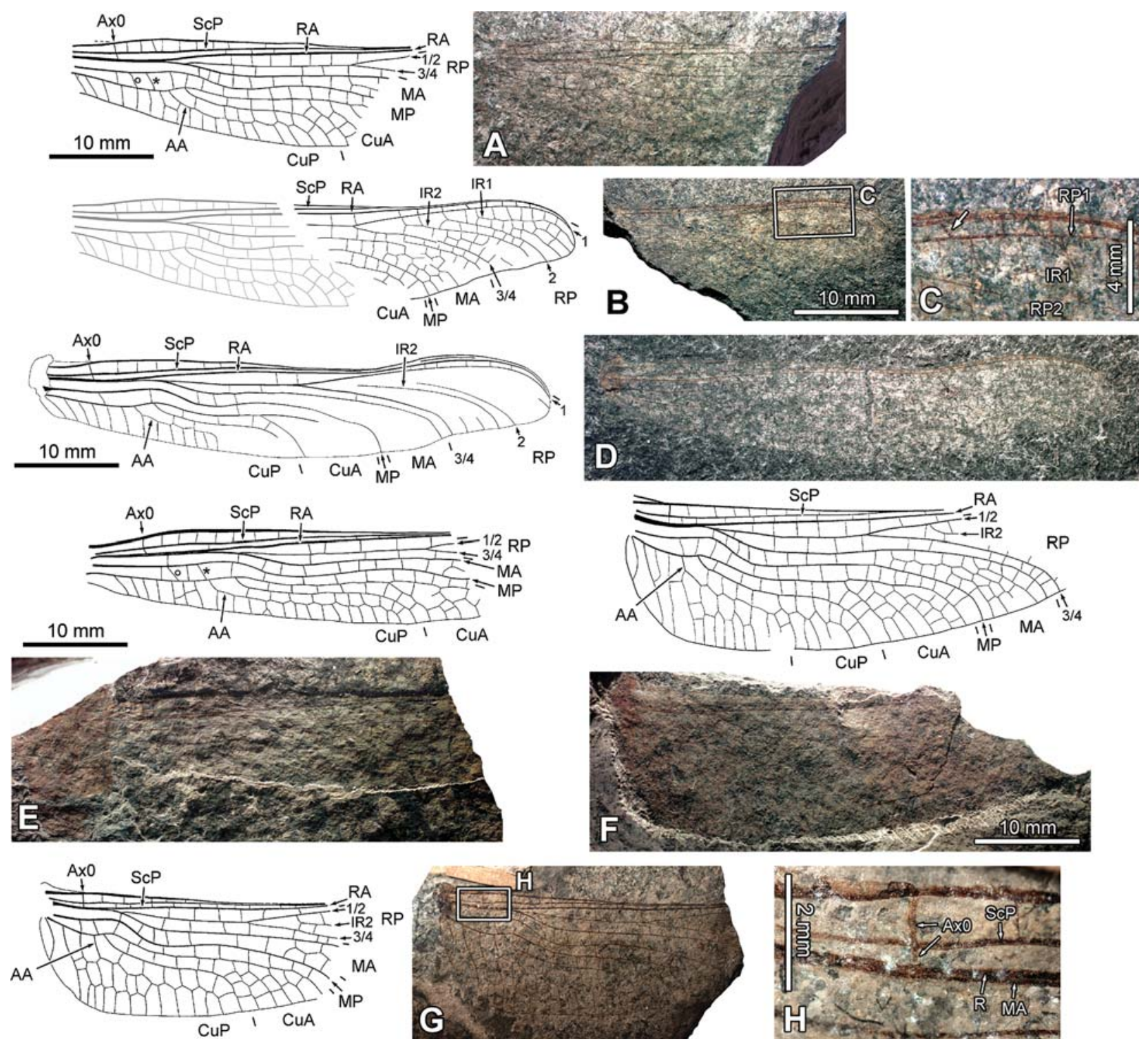

Figure 5. Erasipterella jini (Zhang, Hong \& Su, 2012 in Su et al. 2012) n. comb.; A. Specimen CNU-NX1-443, drawing and photograph (left forewing, negative imprint); B, C. Specimen CNU-NX1-444; B. Drawing (with addition from specimen CNUNX1-443, A) and photograph (right forewing, positive imprint); C. Detail of wing antero-apical area, as located on B (photograph under ethanol only; arrow indicates the 'strong distal oblique'/'postsubnodal' cross-vein); D. Specimen CNU-NX1-441, drawing and photograph (right forewing, positive imprint); E. Specimen CNU-NX1-458, drawing and photograph (left forewing, negative imprint); F. Specimen CNU-NX1-440, drawing and photograph (right hind wing, positive imprint); G-H. Specimen CNU-NX1459 (left hind wing, negative imprint); G. Drawing and photograph (negative imprint); H. Detail of antenodal cross-vein (Ax0), as located on $\mathrm{G}$ (photograph under ethanol only).

458 (Fig. 5E), CNU-NX1-459 (Figs 5G-H); and additional specimens CNU-NX1-437 (wing with apex missing), CNU-NX1-438 (portion of apex), CUN-NX1-447 (portion of apex).

Commented diagnosis. The lack of data on Erasipterella piesbergensis, known only after the basal halves of a fore- and a hind wing of a single individual, makes comparison with our material strenuous. It must be noted here that, in addition to issues mentioned above, the reconstruction of the forewing of Erasipterella piesbergensis provided by Brauckmann (1983) is inaccurate as for the number of cells in the area between $\mathrm{CuA}$ and $\mathrm{CuP}$ : $\mathrm{CuA}$ is branched opposite the 8th cell occurring in this area [10th cell according to Brauckmann
(1983)]. This constitutes a difference with forewing material of Erasipterella jini, in which 6 cells occupy this area ( 9 vs. 8 in hind wings). More striking is the space occupied by anal area in hind wings: although it is limited in Erasipterella piesbergensis, it occupies more than half of wing width (measured opposite the origin of AA; Figs 5F-G) in Erasipterella jini. Based on these differences it is justified to maintain jini as a distinct species.

General description. Forewing: wing length about $49 \mathrm{~mm}$, width $8.6-9.5 \mathrm{~mm}$; area between anterior wing margin and ScA short, ScA reaching anterior wing margin basal to the CuP-crossing; Ax0 located opposite the 
end of ScA; ScP reaching anterior wing margin between the first fork of RP and the origin of IR2; RA simple and straight; first RP fork distal to wing midlength; RP1, RP2, and RP3/4 simple, IR1 and IR2 with about three branches each; MA slightly undulated, stronger than RP, with 3-4 posterior branches (including putative intercalaries); MP strongly undulated basally, simple; CuP- and CuA-crossings distinct, oblique, located basal to the origin of $\mathrm{AA}$; distal part of $\mathrm{CuA}$ only weakly undulated, with about 5 branches (including putative intercalaries); main stem of $\mathrm{CuP}$ basally parallel to posterior margin, bent towards posterior wing margin opposite the first fork of $\mathrm{CuA}$; main stem of AA aligned with cross-veins between branches of $\mathrm{CuP}$, making branches of $\mathrm{CuP}$ indiscernible (if any); cubito-anal and anal areas very narrow; AP simple, short and oblique, reaching posterior wing margin near wing base.

Hind wing: similar to forewings except for the area between $\mathrm{CuP}$ and $\mathrm{AA}$, and the posterior wing margin, broader, accounting for more than half of wing width opposite the origin of $\mathrm{AA}$; $\mathrm{CuP}$ branches distinct from AA, amounting to 5-6 (including putative intercalaries).

Descriptions. Specimen CNU-NX1-443 (Fig. 5A): moderately well preserved basal $2 / 3$ of left forewing, negative imprint, preserved length $32.3 \mathrm{~mm}$, widest area $9.5 \mathrm{~mm}$; stem of radial veins about $9 \mathrm{~mm}$ long; $\mathrm{RP}+\mathrm{MA} 2.0 \mathrm{~mm}$ long; free part of RP $15.9 \mathrm{~mm}$ long basal to the RP1/2 / RP3/4 fork; first branch of MA opposite the first fork of RP; $\mathrm{CuP}$ - and $\mathrm{CuA}$-crossings distinct and oblique, both located basal to the origin of $\mathrm{AA} ; \mathrm{CuA}$ and $\mathrm{CuP}$ distal divergence opposite the RP / MA fork; CuA only partly preserved, with 4 posterior branches preserved (including putative intercalaries, if any), first one located $12.0 \mathrm{~mm}$ distal to the origin of $\mathrm{CuA}$ (from $\mathrm{CuA}+\mathrm{CuP}$ ); main stem of $\mathrm{AA}$ aligned with cross-veins between branches of $\mathrm{CuP}$ (if any).

Specimen CNU-NX1-444 (Figs 5B-C): moderately well preserved fragment of right forewing apex, positive imprint, preserved length $27.1 \mathrm{~mm}$, widest area $9.0 \mathrm{~mm}$; ScP reaching anterior wing margin opposite the origin of IR2; near the apex, area between RA and RP1 with several strong cross-veins, with one particularly strong, and oblique (Fig. 5C), located distal to the origin of RP2 and basal to the origin of IR1; IR1 zigzagged and curved, with two posterior branches and a putative intercalary between them; posterior branches of IR2 and of MA not well preserved; MP simple.

Specimen CNU-NX1-441 (Fig. 5D): poorly preserved right forewing, positive imprint, preserved length $49.0 \mathrm{~mm}$, widest area $8.6 \mathrm{~mm}$; wing shape altered opposite the end of MP, probably as a result of damage or compression of the original three-dimensional structure of the wing; ScA reaching wing apex near wing base; portion of $\mathrm{ScP}$ distinct from anterior wing margin distal to the origin of IR2 (maybe as a consequence of local wing disruption); stem of radial veins $8.6 \mathrm{~mm}$ long;
$\mathrm{RP}+\mathrm{MA} 2.6 \mathrm{~mm}$ long; free part of RP $12.9 \mathrm{~mm}$ long basal to the RP1/2 / RP3/4 fork; RP1/2 and RP3/4 well divergent at their origin; radial area poorly preserved; $\mathrm{CuA}$ branched $10.3 \mathrm{~mm}$ distal to its origin; AP simple and short.

Specimen CNU-NX1-458 (Fig. 5E): fragment of a well preserved left forewing (attached to a fragmentary thoracic remain), negative imprint, preserved length $37.0 \mathrm{~mm}$, widest area $8.7 \mathrm{~mm}$; stem of radial veins about $11.6 \mathrm{~mm}$ long; RP + MA 3.0 long; free part of RP $18.0 \mathrm{~mm}$ long basal to the RP1/2/RP3/4 fork; first branch of MA slightly distal to the first fork of RP; two cells between $\mathrm{CuP}$ - and $\mathrm{CuA}$-crossings; $\mathrm{CuA}$-crossing located opposite the origin of AA; distal free part of $\mathrm{CuA}$ branched $14.8 \mathrm{~mm}$ distal to its origin, with 4-5 preserved branches; main stem of AA aligned with cross-veins between branches of $\mathrm{CuP}$ (if any).

Specimen CNU-NX1-440 (Fig. 5F): moderately well preserved right hind wing, positive imprint, apex missing, preserved length $42.2 \mathrm{~mm}$, widest area $13.8 \mathrm{~mm}$; ScA reaching anterior wing margin near wing base; $\mathrm{ScP}$ reaching wing margin distal to the $\mathrm{RP} 1 / 2 / \mathrm{RP} 3 / 4$ fork, and basal to the origin of IR2; stem of radial veins $6.7 \mathrm{~mm}$ long; RP + MA $1.1 \mathrm{~mm}$ long; free part of RP $14.9 \mathrm{~mm}$ long basal to the RP1/2 / RP3/4 fork; base of IR2 $6.0 \mathrm{~mm}$ distal to the RP1/2/RP3/4 fork; RP3/4 simple, smoothly curved; MA smoothly bent, with five branches (including putative intercalaries) reaching posterior wing margin; MP simple, strongly undulated basally, posteriorly bent near wing margin; distal divergence of $\mathrm{CuA}$ and $\mathrm{CuP} 6.8 \mathrm{~mm}$ from wing base; $\mathrm{CuA}$ branched $14.3 \mathrm{~mm}$ distal to its origin, with 5-6 posterior branches (including putative intercalaries); CuP branched $8.5 \mathrm{~mm}$ distal to its origin, with 5-6 posterior branches (including putative intercalaries); AA with many posterior branches, anal area $7.8 \mathrm{~mm}$ wide at the level of base of AA; AP simple and strong.

Specimen CNU-NX1-459 (Figs 5G-H): very well preserved left hind wing, positive and negative imprints, distal half missing, preserved length $28.7 \mathrm{~mm}$, widest area $11.3 \mathrm{~mm}$; Ax0 located opposite the end of ScA, strong (Fig. 5H); RP + MA about $0.8 \mathrm{~mm}$ long; free part of RP $12.1 \mathrm{~mm}$ long basal to the RP1/2 / RP3/4 fork; MP simple; $\mathrm{CuA}$ with 5 posterior branches (including putative intercalaries); AA with several branches (distally not distinguishable from $\mathrm{CuP}$ branches); anal area $6.6 \mathrm{~mm}$ wide at the level of base of AA; AP simple and strong.

Specimen CNU-NX1-442 (Fig. 6): moderately well preserved individual, negative and positive imprints, with head and thorax overlapping, seven segments of abdomen, remains of four leg preserved, and basal part of four wings attached to thorax.

Head: nearly circular, $38.8 \mathrm{~mm}$ wide, no evident details visible.

Thorax: about $17 \mathrm{~mm}$ long, $9.7 \mathrm{~mm}$ wide in the middle area, with prothorax well delimited, narrower than pterothorax. 

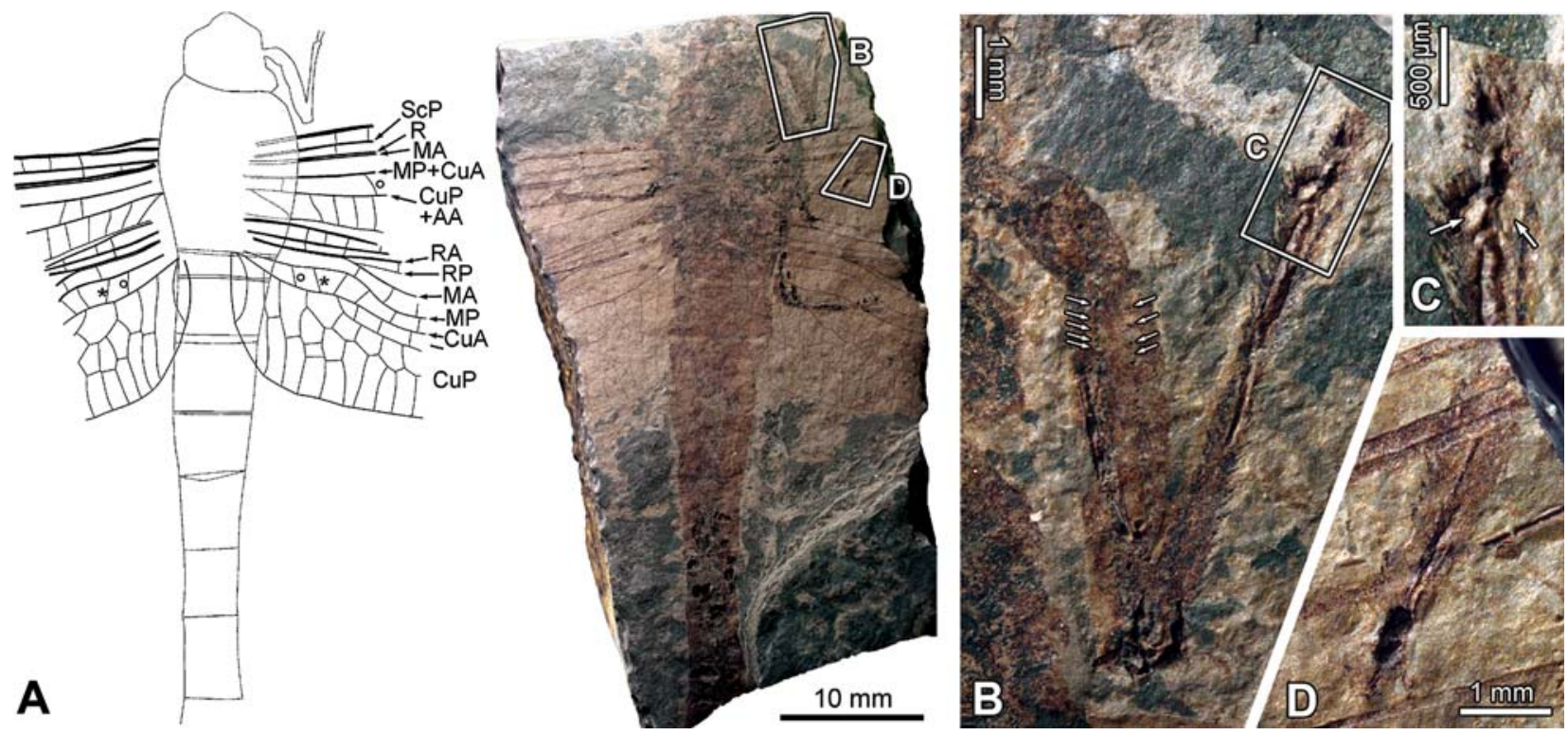

Figure 6. Erasipterella jini (Zhang, Hong \& Su, 2012 in Su et al. 2012) n. comb., specimen CNU-NX1-442; A. Drawing and photograph (negative imprint); B. Detail of left fore-leg, as located on A (some of the insertions points of femoral spines indicated by arrows); C. Detail of left fore-leg tarsus, as located on B, with segments tentatively indicated (arrows indicate plantulae); D. Detail of left mid-leg tibia, as located on A.

Abdomen: about $33 \mathrm{~mm}$ long as preserved, basally $5.8 \mathrm{~mm}$ wide but slightly narrower distally; with 8 segments preserved, first one narrower than others.

Left fore-leg (Figs 6B-C): preserved in ventral view, coxa about $1.1 \mathrm{~mm}$ long, femur about $4.3 \mathrm{~mm}$ long, bearing spines (indicated by their insertion point; arrows on Fig. $5 \mathrm{H}$ ), aligned in two longitudinal rows; tibia about $5.4 \mathrm{~mm}$ long, bearing longer and stronger spines, and a pair of rounded plantulae at apex (arrows on Fig. 6C); all tarsal segments (number undetermined) with short spines.

Left mid-leg (Fig. 5D): mostly composed of fragment of tibia in lateral view, bearing small and aligned spines.

Forewings: right and left forewing preserved length $9.8 \mathrm{~mm}$ and $10.5 \mathrm{~mm}$, respectively; area between anterior wing margin and ScA preserved in left forewing; AP simple, strong.

Hind wings: area between anterior wing margin not preserved (or visible); right and left hind wings preserved length $10.2 \mathrm{~mm}$ and $14.8 \mathrm{~mm}$, respectively, maximum width $11.2 \mathrm{~mm}$.

Left hind wing: stem of radial veins about $8 \mathrm{~mm}$ long; $\mathrm{RP}+\mathrm{MA} 0.9 \mathrm{~mm}$ long; distal divergence of $\mathrm{CuA}$ and $\mathrm{CuP} 7.5 \mathrm{~mm}$ from wing base; base of AA between $\mathrm{CuP}$ - and CuA-crossings; anal area $6.9 \mathrm{~mm}$ wide opposite the base of AA.

Discussion. The assignment of specimens reproduced on Figs 5-6 to a single species is straightforward, as they have very similar sizes and wing venation patterns. The specimen CNU-NX1-444 (Fig. 5B), composed of an apical portion, is a perfect match to the specimen CNU-NX1-443 (Fig. 5A; basal two thirds of a forewing), and this assemblage is corroborated by data on the specimens CNU-NX1-441 (Fig. 5D; a complete forewing). Association of an isolated hind wing (CNUNX1-440; Fig. 5F) with forewing is ascertained by data on Erasipterella piesbergensis, and by the specimen CNU-NX1-442 (Fig. 6), associating fore- and hind wings. Finally assignment of the new specimens to Erasipterella jini is straightforward, as no major differences exist with the holotype ( $\mathrm{Su}$ et al. 2012, figs 1-3; although the description by these authors indicates a width of $9.5 \mathrm{~mm}$, measurement based on their fig. 1 indicates a width of $9.2 \mathrm{~mm}$; in any case both values are compatible with the range observed in the new set of specimens). The location of $\mathrm{CuP}-$ and $\mathrm{CuA}$-crossings seems to vary, although to a limited extent, in this species.

\section{Aseripterella n. gen.}

Derivation of name. Anagram of Erasipterella, a taxon including species possibly related to the type species.

Composition. Aseripterella sinensis n. sp.

Diagnosis. By monotypy, that of the type species.

\section{Aseripterella sinensis $\mathbf{n}$. sp.}

Figure 7

Derivation of name. Named according its known occurrence (viz., in China).

Material. Holotype specimen CNU-NX1-454 (Figs 7A-B), and specimens CNU-NX1-450 (Fig. 7C), CNU-NX1-451 (Fig. 7D).

Commented diagnosis. The occurrence of a single row of cross-veins in the area between AA and the posterior wing margin distinguishes $A$. sinensis $\mathrm{n}$. sp. from spe- 


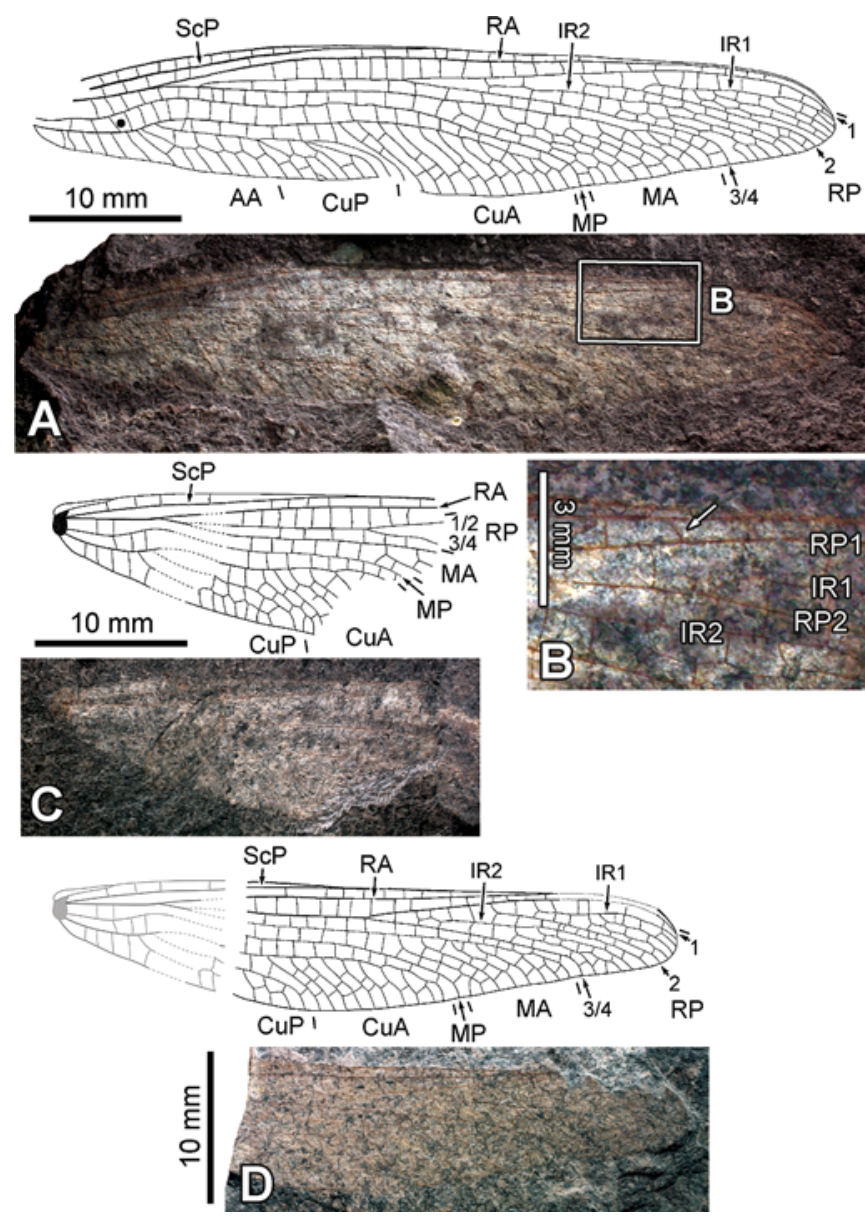

cies of meganisopteran Odonatoptera, such as Shenzhousia spp. (Fig. 1), Oligotypus spp. (Fig. 2), and Tupus spp. Instead, owing to its small size, A. sinensis n. sp. compares to the Erasipterella species. However A. sinensis n. sp. has more numerous branches of MA and $\mathrm{CuA}$ (with nearly the same size), and a more basal $\mathrm{RP} 1 / 2$ / RP3/4 fork, as compared to Erasipterella jini, from the same locality. Other 'Erasipteridae'-like species differ on important traits (e.g. the simple $\mathrm{CuP}$ in Erasipteron larischi), or are too poorly documented to be compared to Sylphalula sinensis n. gen. et sp. For example comparison with Erasipteroides valentini is impossible, as this species is known based on the basal fifth of a forewing (hence lacking most of the relevant characters), and the two basal fifths of a hind wing, unknown in A. sinensis n. sp. Provided the available data it appears justified erecting a new genus and species.

General description. Forewing: (based on all specimens) relatively small, wing length about $41-53 \mathrm{~mm}$, width about 8.2-9.4 mm; precostal area short, ScA reaching anterior wing margin basal to the origin of $\mathrm{AA}$; ScP reaching anterior wing margin opposite the RP1/2 / RP3/4 fork (i.e. opposite wing mid-length); RP1, RP2, and RP3/4 simple; IR1 and IR2 with 2-3 posterior branches; MA slightly bent at its origin, with 7-9 branches (including putative intercalaries); MP simple, moderately undulated; CuP- and CuA-crossings apparently fused in a single crossing; $\mathrm{CuA}$ with $10-11$ posterior branches (including putative intercalaries);
Figure 7. Aseripterella sinensis n. $\mathrm{sp}$; A, B. Holotype specimen CNU-NX1-454; A. Drawing and photograph (left (hind?) wing, positive imprint, flipped horizontally); B. Detail of wing antero-apical area, as located on A (photograph under ethanol only; arrow indicates the 'strong distal oblique'/"postsubnodal' cross-vein); C. Specimen CNU-NX1-450, drawing and photograph (left wing, negative imprint); D. Specimen CNU-NX1-451, drawing (with addition from specimen CNU-NX1-450, B., re-shaped, see text) and photograph (left wing, positive imprint, flipped horizontally).

area between $\mathrm{CuP}$ and posterior wing margin narrow, with a single row of cross-veins between putative branches of CuP; anal area with one row of cells only.

Hind wings?: (based on specimen CNU-NX1-454) $\mathrm{CuP}$ with distinct branches; AA with 5 very short posterior branches, without cross-veins between them.

Descriptions. Holotype specimen CNU-NX1-454 (Figs 7A-B): negative and positive imprints of a moderately well preserved left wing (hind wing?), nearly complete; preserved length $52.9 \mathrm{~mm}$, maximum width $9.4 \mathrm{~mm}$; anterior wing margin and $\mathrm{ScP}$ bent and posterior wing margin disrupted, probably as a consequence of damage done to the wing prior to fossilization; $\mathrm{ScP}$ reaching anterior wing margin opposite the RP1/2 / RP3/ 4 fork (i.e. opposite wing mid-length); area between RA and RP1 with a strong oblique cross-vein distal to the origin of RP2 and basal to the origin of IR1 (arrow Fig. 7B); stem of radial veins $7.8 \mathrm{~mm}$ long; RP + MA $2.7 \mathrm{~mm}$ long; free part of RP $13.5 \mathrm{~mm}$ long basal to the RP1/2 / RP3/4 fork; IR1 with 4-5 posterior branches; $\mathrm{RP} 1 / \mathrm{RP} 2$ fork $11.5 \mathrm{~mm}$ distal of the RP1/2 / RP3/4 fork; IR2 with 3 posterior branches (probably 2 and an intercalary); MA with 8 posterior branches (putatively including intercalaries) reaching posterior wing margin; MP slightly undulated; CuA regularly posteriorly pectinate, with 11 posterior branches (including putative intercalaries); $\mathrm{CuP}$ - and $\mathrm{CuA}$-crossings difficult to identify, apparently forming a single crossing; $\mathrm{CuP}$ with 7-8 
branches (including putative intercalaries); AA with 5 very short posterior branches, without cross-veins between them.

Specimen CNU-NX1-450 (Fig. 7C): moderately well preserved left wing, basal half, negative imprint, preserved length $25.3 \mathrm{~mm}$, maximum width $9.3 \mathrm{~mm}$; ScA reaching anterior wing margin basal to the origin of $\mathrm{AA}$; stem of radial veins $6.8 \mathrm{~mm}$ long; $\mathrm{RP}+\mathrm{MA}$ $2.0 \mathrm{~mm}$ long; free part of RP about $12 \mathrm{~mm}$ long basal to the RP1/2 / RP3/4 fork; CuA poorly preserved, with at least 6 posterior branches; main stem of $\mathrm{CuP}$ relatively short, with four or five very short and indistinct posterior branches.

Specimen CNU-NX1-451pc (Fig. 7D): fragment left wing, positive and negative imprints, basal third missing; preserved length $28.9 \mathrm{~mm}$, maximum width $8.2 \mathrm{~mm}$; IR1 with 3 posterior branches (putatively 2 and an intercalary); RP2 emerging from RP $8.2 \mathrm{~mm}$ distal of the base of RP3/4; IR2 with 2 posterior branches; MA with 7 posterior branches, $\mathrm{CuA}$ with 10 posterior branches; CuP partly preserved with several posterior branches, with a single cross-vein between them.

Discussion. Assignment of the specimens reproduced on Fig. 7 to the same species is straightforward. Basically their respective sizes fit within the range of intraspecific variability known in extant Odonatoptera (see above), and the specimen CNU-NX1-450 is a perfect fit to the specimen CNU-NX1-451 (assemblage on Fig. 7D). Variation in the number of $\mathrm{MA}$ and $\mathrm{CuA}$ branches is obviously related to variation in size. The only significant difference between the specimens CNU-NX1-454 and -450 regards the area between $\mathrm{CuP}$ and the posterior wing margin, wider and with distinct branches in the former. Material of Erasipterella jini (Fig. 5) has shown that in this species distinct branches of $\mathrm{CuP}$ tend to occur in hind wings, but are absent in forewings (or cannot be distinguished). This leads us to presume that the specimen CNU-NX1-454 could be a hind wing (and the specimen CNU-NX1-450 a forewing lacking distinct $\mathrm{CuP}$ branches).

\section{Sylphalula n. gen.}

Derivation of name. Based on 'Sylphus' (Latin), a fairy-like spirit of the air in Western tradition, and 'alula', 'little wing' in Latin.

Composition. Sy. laliquei n. sp.

Diagnosis. By monotypy, that of the type species.

\section{Sylphalula laliquei n. sp.}

Figure 8

Derivation of name. Dedicated to René Jules Lalique, renowned for his interest in sylph-like creatures.

Material. Holotype specimen CNU-NX1-452 (Fig. 8).

Commented diagnosis. In addition to its small size, $S y$. laliquei n. sp. is distinctive in its low number of

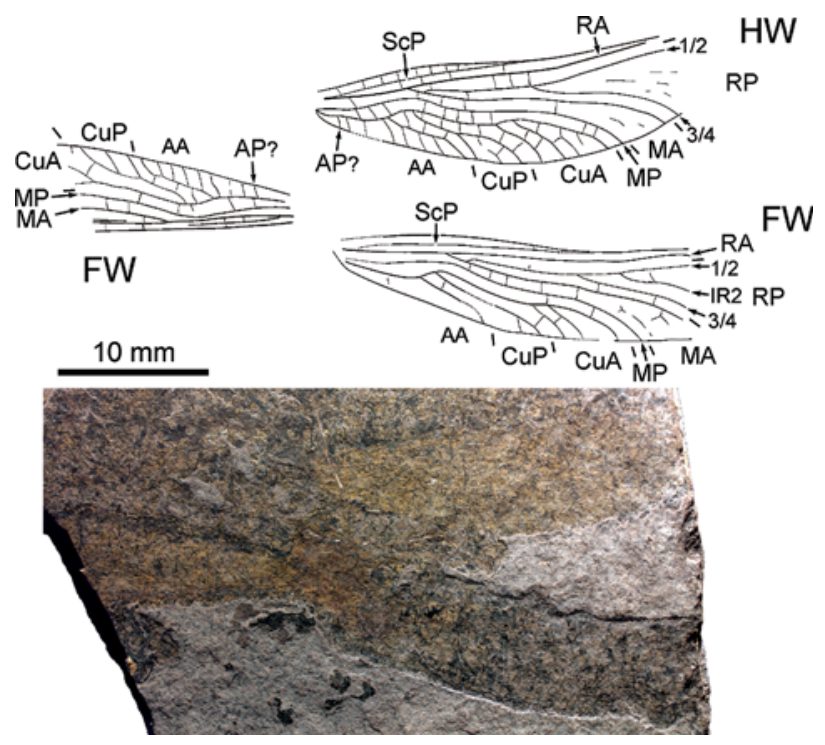

Figure 8. Sylphalula laliquei n. gen. et sp; holotype specimen CNU-NX1-452, drawing and photograph (positive imprint).

branches of MA, $\mathrm{CuA}$, and $\mathrm{CuP}$ in both wing pairs (as opposed to the condition observed in A. sinensis n. sp., for example; Fig. 7). The absence of cross-veins between AA branches in hind wings is also a distinctive trait of the species (as opposed to the condition in Erasipterella spp., for example; Fig. 5). Therefore erection of a new species (and genus) appears justified.

Description. Holotype specimen CNU-NX1-452 (Fig. 8): positive and negative imprints of a poorly preserved individual, composed of two forewings (left and right cannot be determined) and one hind wing (apices missing), in connection to pterothorax; poorly preserved abdomen remains.

Forewings: longest preserved length $24.5 \mathrm{~mm}$, estimated total length about $32 \mathrm{~mm}$, widest area $6.1 \mathrm{~mm}$; anterior wing margin smoothly curved; ScP nearly straight, reaching anterior wing margin opposite the first fork of RP; stem of radial veins about $7.4 \mathrm{~mm}$ long; RP + MA $1.4 \mathrm{~mm}$ long; RP oblique at its origin (from RP + MA), simple for $7.6 \mathrm{~mm}$; RP3/4 simple; main stem of MA smoothly curved, with few posterior branches (number unknown but probably less than five); MP simple, smoothly undulated; CuA undulated, with three posterior branches preserved; $\mathrm{CuP}$ with three posterior branches (probably two with one intercalary); AA short, with five short posterior branches, without cross-veins between them; anal area narrow $(1.4 \mathrm{~mm}$ wide at the level of base of AA).

Hind wing: preserved length $23.7 \mathrm{~mm}$, widest area $6.9 \mathrm{~mm}$; wing venation similar to that of forewings, slightly wider; origin of stem of RP + MA $6.2 \mathrm{~mm}$ distal to wing base, $1.1 \mathrm{~mm}$ long; $\mathrm{CuA}$ - and CuP-crossings not obvious; $\mathrm{CuA}$ with five posterior branches (including putative intercalaries); AA with four distinct short posterior branches; anal area $1.6 \mathrm{~mm}$ wide opposite the origin of AA. 


\section{Discussion}

Is the 'strong distal oblique' cross-vein the subnodal cross-vein?

The 'strong distal oblique' cross-vein in the area between RA and RP and located close to the origin of $\mathrm{RP} 2$, observed in meganeuridaeans, was considered as "typical" of the family Meganeuridae by $\mathrm{Nel}$ et al. (2009; and as the only useful diagnostic character indeed). However Bechly (1996, p. 40) suggested that this oblique cross-vein might be a homologous structure to the genuine subnodal cross-vein of Odonata (located more basally in these insects). This interpretation was challenged by Nel et al. (2009, p. 95), concurring with Nel et al. (2008), stating that the meganeuridaean subnodal cross-vein is "not exactly homologous with the nodialatan subnodus as it probably did not have the same function". This argumentation is obviously flawed: fingers in bats and humans serve different functions, yet are homologous. Whether the 'strong distal oblique' cross-vein is homologous to the subnodus is to be discussed in the light of the new data.

The 'strong distal oblique' cross-vein occurs more extensively than assumed by $\mathrm{Nel}$ et al. (2009). In addition to several meganeuridaean Odonatoptera such as Sh. qilianshanensis (Zhang et al. 2006, fig. 1; Fig. 1B) and $T$. orientalis (Fig. 4C), it was observed in O. huangheensis [Figs 2G-H; although the species was assigned to the Meganeuridae by Nel et al. (2009), we argue above that it belongs to the genus Oligotypus, itself assigned to the Paralogidae by Nel et al. (2009)], and in the 'erasipteridaean' Erasipterella jini ( $\mathrm{Su}$ et al. 2012, figs 1-3; Figs $5 \mathrm{~B}-\mathrm{C}$ ). We found no ground to follow $\mathrm{Su}$ et al. (2012) assumption of a convergent acquisition between Erasipterella jini and meganisopteran Odonatoptera. Instead we assume that this trait is characteristic of a clade larger than previously expected.

In this context, it is worth examining the Triadophlebiomorpha, a group of fossil Odonatoptera possessing an elaborated nodus and arculus (as compared to that of meganisopteran Odonatoptera). Several members of this group are known to possess both a subnodal crossvein, as well as a 'strong distal oblique' cross-vein between RA and RP, the latter in a location similar to that observed for a similar structure in meganisopteran Odonatoptera (Pritykina 1981; Bechly 1996). Even, according to an interpretation of the Ditaxineuridae wing venation by Bechly (1996, fig. 17, p. 271), this group also possesses both structures.

There is a significant phylogenetic distance between Triadophlebiomorpha (and Ditaxineuridae) on one side, and 'erasiperidaean' and meganisopteran Odonatoptera on the other. However the hypothesis that the 'strong distal oblique' cross-vein observed in these groups is homologous cannot be excluded. If so, the subnodal cross-vein cannot be homologous to it, because both co-occur in Triadophlebiomopha (and possibly in Ditaxineuridae). In other words Patterson's (1982) con- junction test fails for the subnodal and the 'distal oblique' cross-veins. If correct, a consequence is that the Meganeuridae are left with no diagnostic character. We propose to name the 'distal oblique' cross-vein 'postsubnodal'.

\section{A range of sizes from another time}

Representatives of the Paleozoic meganisopteran Odonatoptera are renowned for their exceptionally large size, including the largest insect ever found, Meganeuropsis permiana Carpenter, 1939, with a wingspan of about $710 \mathrm{~mm}$ (see original description). It has been suggested that comparatively high atmospheric oxygen concentration prevailing during the Pennsylvanian and the Early Permian might have been the main factor responsible for gigantism observed in arthropods of this period, and in Odonatoptera in particular (Graham et al. 1995; Dudley 1998, 2000). Indeed it has been demonstrated that intense metabolic activities, such as flight performing in Odonatoptera, benefit from hyperoxic conditions (Harrison \& Lighton 1998). Therefore such conditions might have allowed larger species, demanding more oxygen intake to operate, to evolve. In connection with this aspect, hyperoxia might have lifted limitations related to the need to possess a proportionally larger respiratory system in larger insect individuals (Kirkton 2007) and species (Harrison et al. 2010; Kaiser et al. 2007). However large Odonatoptera have been documented from the Middle/Late Permian Lodève locality, when the putative oxygen concentration was decreasing ( Nel et al. 2008). Therefore other limitative factors (or their lack thereof) are to be considered. Among them, the role of mean temperature is unclear, as both high and low temperature levels have been deemed to induce gigantism [in contrast to Makarieva et al. (2005) and Harrison et al. (2010)].

Biotic factors could have played an important role. The existence of multi-level food webs, possibly including primary and secondary predators, was an important premise for the evolution of gigantic predatory Odonatoptera. Indeed the Pennsylvanian biotic environment offered such favourable conditions. The sample from the Xiaheyan locality demonstrates that Odonatoptera occupied a large variety of size niches, and that a large choice of preys was available to these insects: with a wingspan reaching about $20 \mathrm{~mm}$, relatively small species such as the grylloblattid Sinonamuropteris ningxiaensis Peng et al., 2005 (revised in Cui et al. 2011) and the stonefly Gulou carpenteri Béthoux et al., 2011 could have made proper prey items to Sy. laliquei n. gen. et sp., while abundant larger stem-Orthoptera, such as Longzhua loculata Gu et al., 2011, and the gracile Megasecoptera (remaining to be described), could have been suited for larger Odonatoptera. Provided the rarity of very large Palaeodictyoptera in the Xiaheyan fauna, such as Namuroningxia elegans Prokop \& Ren, 2007 (OB pers. obs.), it is likely that Sh. qilianshanen- 
sis preyed upon smaller Odonatoptera as well, in particular the comparatively abundant (or over-sampled) T. orientalis. Such 'mutual' predation is well documented in extant Odonatoptera (Corbet 2004).

Another biotic aspect to consider is that the evolutionary pathway towards gigantism probably was freed by the lack of groups nowadays competing with, and foraging on, Odonatoptera (Bechly 2004; Corbet 2004; Nel et al. 2008; and see Bechly 2001), such as flying vertebrates Indeed the 'large flying predators' niche has been the reserved playground of Odonatoptera during the whole Late Palaeozoic. The lack of predators sufficiently agile to forage on large Odonatoptera must also be emphasized. Under such permissive settings, and provided that extant large species of Odonatoptera are inclined to be territorial (Johansson et al. 2005), it can also be assumed that competition for securing territory and resources acted as an additional positive driver for gigantism in the group. In summary it appears that both abiotic and biotic conditions were particularly favourable for the evolution of gigantism in Odonatoptera during the Late Palaeozoic, a unique event in insect history.

\section{Ties between Pennsylvanian and Permian faunas}

On the continental realm the transition from the Pennsylvanian to Permian times is characterized by important environmental modifications. Alterations of plant communities constitute a solid evidence of these changes, and received considerable attention. Taken globally, it has long been admitted that dominant wetland plant communities were progressively replaced by xerophytic assemblages (Kerp 2000; DiMichele et al. 2001; among others). With more details, this replacement is characterized by the spatial and temporal alternation of distinct and independent biomes (DiMichele et al. 2008), sudden threshold-type changes within a biome (DiMichele et al. 2008), and large-scale floristic migrations and colonisations (for the Northern hemisphere, see Hilton \& Cleal 2007). From a climatic perspective, the interval is characterized by a global aridization, possibly driven by an increase in atmospheric concentrations of $\mathrm{CO}_{2}$ (Montañez et al. 2007; see Hilton \& Cleal 2007, and references therein, for alternative and possibly complementary causal mechanisms), and increased seasonality (Schneider et al. 2006).

Were insects affected by these environmental modifications is far from clear. This is mainly due to the lack of quantitative data for Pennsylvanian and Permian faunas (with few exceptions, such as Beckemeyer \& Hall 2007), and the persistence of large para- and polyphyletic groups in the systematics of insects of this interval. In addition species delimitation widely varied among authors [e.g., see revisions of Pennsylvanian species by Béthoux (2008), Cui et al. (2011), and Schneider (1983)]. The limited relevant data, based on the few groups that benefited from a 'phylogenetic' classification, indicate that the diversity of some particular insect groups decreased during the Pennsylvanian-Permian transition (Béthoux 2005, 2007). In addition the grylloblattid insects, documented by very few species during the Pennsylvanian (Béthoux \& Nel 2010; Cui et al. 2011), in contrast represent a major component of Permian faunas (Beckemeyer \& Hall 2007). Provided that various specific plant-insect interactions, indicative of plant-related preferences by insects, have been documented during the Pennsylvanian (Lesnikowska 1990; Labandeira \& Phillips 2002; Béthoux et al. 2004; Labandeira 2006), it could be anticipated that floristic modifications could have had a strong impact on insect faunas.

The new data on the systematics of Odonatoptera from the Xiaheyan locality rather contradicts this prediction. Although the wide temporal and geographic occurrence of taxa such as Tupus is of difficult interpretation because they likely are a rag-bags, that of species assigned to the well-constrained genera Shenzhousia and Oligotypus in both the Xiaheyan and Elmo (Artinskian, Lower Permian) localities indicate that the corresponding lineages were unaffected by PennsylvanianPermian disturbances. This resilience could be explained by the strong flight, hence dispersal capacities of these insects. Indeed the two localities were geographically distant at the time, indicating a migration of these insects or, more likely, a widespread distribution during the Pennsylvanian-Permian interval. The latter assumption is supported by the nearly contemporaneous occurrence of Erasipterella species in both the Osnabrück (Germany) and the Xiaheyan localities, widely distant at the time. It must be assumed that Pennsylvanian Odonatoptera have been able to adapt their diet to a changing environment. Finally, it is noticeable that extant Odonatoptera facing of the current biodiversity crisis were found to be particularly resilient, as compared to other insect groups (Clausnitzer et al. 2009).

\section{Conclusion}

The available data on Pennsylvanian Odonatoptera was found to render laborious the description of the new material from the Xiaheyan locality. Indeed the available information is replete with species based on fragmentary (or very fragmentary) material, and which often have been assigned to their own (hence monotypic) genus (or (sub-)family). We consider a sensible option to admit that developing a detailed, familial taxonomic scheme on these data is premature at the moment.

Thanks to the comparatively large number of available specimens, the species revised and described in this contribution are among the best known Odonatoptera of the Pennsylvanian. The available data entailed a reconsideration of taxonomic affinities of several species previously described.

The documentation at hand pictures a Pennsylvanian Odonatoptera fauna very diverse in terms of size (and, 
therefore, ecological niche), corroborating the view that insects already experienced a long evolutionary history prior to this period (Béthoux et al. 2011). Affinities between Pennsylvanian Odonatoptera and their Permian relatives are hypothesized, indicating that these particular insects were not significantly affected by environmental changes which occurred at the PennsylvanianPermian transition.

\section{Acknowledgments}

We thank J. W. Schneider and G. Bechly (GB) for useful comments, the editors of the journal, R. Beckemeyer, J. Prokop, and GB for prompt assistance with literature data, Z. Zhang for allowing a loan of material housed at the Geological Museum (Beijing, China), C. Brauckmann and K. J. Herd for sharing unpublished data on Erasipterella piesbergensis, Y. Cui for assistance with photographs, and P. Selden, X. Yu, and D. Zhou for valuable discussion. This research is supported by grants from National Basic Research Program of China (973 Program) (2012CB821906), the National Nature Science Foundation of China (41272006, 31230065, 31071964, 31172143,), China Geological Survey (1212011120116), Scientific Research Key Program (KZ201310028005)

\section{References}

Bechly, G. 1996. Morphologische Untersuchungen am Flügelgeäder der rezenten Libellen und deren Stammgruppenvertreter (Insecta; Pterygota; Odonata) unter besonderer Berücksichtigung der Phylogenetischen Systematik und des Grundplanes der Odonata. - Petalura, special volume 2: 1-402.

Bechly, G. 2001. Das Sterben der Riesen. In Bechly, G., Haas, F., Schawaller, W., Schmalfuss, H. \& Schmid, U. (eds). Ur-Geziefer Die faszinierende Evolution der Insekten. - Stuttgarter Beiträge zur Naturkunde (C) 49: 39-42.

Bechly, G. 2004. Evolution and systematics. In Hutchins, M., Evans, A. V., Garrison, R. W. \& Schlager, N. (eds). Grzimek's Animal Life Encyclopedia 2nd ed, vol. 3. Gale, Farmington Hills: pp. 716 .

Bechly, G. 2007. Phylogenetic Systematics of Odonata. http:// www.bernstein.naturkundemuseum-bw.de/odonata/phylosys.htm

Bechly, G., Brauckmann, C., Zessin, W. \& Gröning, E. 2001. New results concerning the morphology of the most ancient dragonflies (Insecta: Odonatoptera) from the Namurian of Hagen-Vorhalle (Germany). - Journal of Zoological Systematics and Evolutionary Research 39: 209-226.

Beckemeyer, R. J. \& Engel, M. S. 2011. Upper Carboniferous insects from the Pottsville Formation of Northern Alabama (Insecta: Ephemeropteridae, Palaeodictyopterida, Odonatoptera). - Scientific Papers, Natural History Museum, The University of Kansas 44: $1-19$.

Beckemeyer, R. J. \& Hall, J. D. 2007. The entomofauna of the Lower Permian fossil insect beds of Kansas and Oklahoma, USA. - African Invertebrates 48 (1): 23-39.

Béthoux, O. 2005. Cnemidolestodea (Insecta): an ancient order reinstated. - Journal of Systematic Palaeontology 3 (4): 403-408.

Béthoux, O. 2007. Ordinal assignment of the genus Tococladus Carpenter, 1996 (Insecta: Archaeorthoptera). - Alavesia 1: 3.

Béthoux, O. 2008. Revision and phylogenetic affinities of the lobeattid species bronsoni Dana, 1864 and silvatica Laurentiaux \& Laurentiaux-Vieira, 1980 (Pennsylvanian; Archaeorthoptera). Arthropod Systematics \& Phylogeny 66 (2): 145-163.
Béthoux, O. 2010. Optimality of phylogenetic nomenclatural procedures. - Organisms Diversity \& Evolution 10 (2): 173-191.

Béthoux, O., Cui Yingying, Kondratieff, B., Stark, B. \& Ren Dong 2011. At last, a Pennsylvanian stem-stonefly (Plecoptera) discovered. - BMC Evolutionary Biology 2011 (11): 248.

Béthoux, O., Galtier, J. \& Nel, A. 2004. Earliest evidence of insect endophytic oviposition. - Palaios 19 (4): 408-413.

Béthoux, O. \& Jarzembowski, E. A. 2010. New basal neopterans from Writhlington (UK, Pennsylvanian). - Alavesia 3: 87-96.

Béthoux, O. \& Nel, A. 2010. Description of a new grylloblattidan insect from Montceau-les-Mines (Pennsylvanian; France) and definition of Phenopterum Carpenter, 1950. - Systematic Entomology 35 (3): 546-553.

Béthoux, O. \& Wieland, F. 2009. Evidence for Carboniferous origin of the order Mantodea (Insecta: Dictyoptera) gained from forewing morphology. - Zoological Journal of the Linnean Society 156 (1): 79-113.

Brauckmann, B. 1983. Ein Insektenrest (Odonata: Meganisoptera) aus dem Ober-Karbon des Piesberges bei Osnabrück. - Osnabrücker naturwissenschaftliche Mitteilungen 10: 7-14.

Brauckmann, C. 1988. Zwei neue Insekten (Odonata, Megasecoptera) aus dem Namurium von Hagen-Vorhalle (West-Deutschland). Dormunter Beiträge zur Landeskunde, Naturwissenschaftliche Mitteilungen 22: 91-101.

Brauckmann, C. \& Herd, K. J. 2003. Insekten-Funde aus dem Westfalium D (Ober-Karbon) des Piesberges bei Osnabrück (Deutschland). Teil 1: Palaeoptera. - Osnabrücker naturwissenschaftliche Mitteilungen 28 (for 2002): 27-69.

Brauckmann, C., Koch, L. \& Kemper, M. 1985. Spinnentiere (Arachnida) und Insekten aus den Vorhalle-Schichten (Namurium B; Ober-Karbon) von Hagen-Vorhalle (West-Deutschland). - Geologie und Paläontologie in Westfalen 3: 1-132.

Brauckmann, C. \& Zessin, W. 1989. Neue Meganeuridae aus dem Namurium von Hagen-Vorhalle (BDR) und die Phylogenie des Meganisoptera. - Deutsche Entomologische Zeitschrift 36 (1-3): $177-215$.

Carpenter, F. M. 1927. A fossil insect from the Lower Permian of the Grand Canyon. - Proceedings of the United States National $\mathrm{Mu}-$ seum 71: 3-4.

Carpenter, F. M. 1928. A new Protodonatan from the Grand Canyon. - Psyche 35: 186-190.

Carpenter, F. M. 1931. The Lower Permian insects of Kansas. Part 2. The orders Palaeodictyoptera, Protodonata, and Odonata. - American Journal of Science (5), 21 (5): 97-139.

Carpenter, F. M. 1933. The Lower Permian Insects of Kansas. Part 6. Delopteridae, Protelytroptera, Plecoptera and a New Collection of Protodonata, Odonata, Megasecoptera, Homoptera, and Psocoptera. - Proceedings of the American Academy of Arts and Sciences 68 (11): 411-503.

Carpenter, F. M. 1939. The Lower Permian insects of Kansas. Part 8 . Additional Megasecoptera, Protodonata, Odonata, Homoptera, Psocoptera, Protelytroptera, Plecoptera, and Protoperlaria. - Proceedings of the American Academy of Arts and Sciences 73 (3): $29-70$.

Carpenter, F. M. 1947. Lower Permian insects from Oklahoma. Part 1 Introduction and the orders Megasecoptera, Protodonata, and Odonata. - Proceedings of the American Academy of Arts and Sciences 76 (2): 25-54.

Carpenter, F. M. 1960. Studies on North American Carboniferous Insects 1. The Protodonata. - Psyche 67 (4): 98-110.

Carpenter, F. M. 1992. Superclass Hexapoda. In Kaesler, R. L. (ed.) Treatise on Invertebrate Paleontology. The Geological Society of America and the University of Kansas, Boulder, pp. xxii +655 .

Charpentier, T. v. 1840. Libellulinae europaeae descriptae ac depictae Voss, L., Leipzig.

Clausnitzer, V., Kalkman, V. J., Ram, M., Collen, B., Baillie, J. E. M., Bedjanič, M., Darwalle, W. R. T., Dijkstra, L.-D. B., Dow, R., 
Hawking, J., Karubeh, H., Malikova, E., Paulson, D., Schütte, K., Suhling, F., Villanueva, R. J., von Ellenrieder, N. \& Wilson, K. 2009. Odonata enter the biodiversity crisis debate: the first global assessment of an insect group. - Biological Conservation 142 (8): 1864-1869.

Cui Yingying, Béthoux, O. \& Ren Dong 2011. Intraindividual variability in Sinonamuropteridae forewing venation (Grylloblattida; Late Carboniferous): taxonomic and nomenclatural implications. Systematic Entomology 36 (1): 44-56.

d'Aguilar, J. \& Dommanget, J.-L. 1998. Guide des libellules d'Europe et d'Afrique du Nord. Delachaux et Nieslé, Lausanne.

Dayrat, B. \& Gosliner, T. M. 2005. Metaphyly and species names: a case study in Discodorididae (Mollusca, Gastropoda, Euthyneura, Nudibranchia). - Zoologica Scripta 34: 199-224.

Dayrat, B., Schander, C. \& Angielczyk, K. 2004. Suggestions for a new species nomenclature. - Taxon 53 (2): 485-491.

DiMichele, W. A., Kerp, H. \& Looy, C. V. 2008. The so-called "Paleophytic-Mesophytic" transition in equatorial Pangea - Multiple biomes and vegetational tracking of climate change through geological time. - Palaeogeography, Palaeoclimatology, Palaeoecology 268: $152-163$.

DiMichele, W. A., Pfefferkorn, H. W. \& Gastaldo, R. A. 2001. Response of Late Carboniferous and Early Permian plant communities to climate change. - Annual Review of Earth and Planetary Sciences 29: 461-487.

Dudley, R. 1998. Atmospheric oxygen, giant paleozoic insects and the evolution of aerial locomotor performance. - Journal of Experimental Biology 201: 1043-1050.

Dudley, R. 2000. The biomechanics of insect flight: form, function, evolution. Princetown University Press, Princetown.

Graham, J. B., Dudley, R., Aguilar, N. M. \& Gans, C. 1995. Implications of the late Palaeozoic oxygen pulse for physiology and evolution. - Nature 375: 117-120.

Grimaldi, D. \& Engel, M. S. 2005. Evolution of the Insects. Cambridge University Press, New York.

Gu Junjie, Béthoux, O. \& Ren Dong 2011. Longzhua loculata n. gen. and n. sp., one of the most completely documented Pennsylvanian Archaeorthoptera (Insecta; Ningxia, China). - Journal of Paleontology 85 (2): 303-314.

Harrison, J. F., Kaiser, A. \& VandenBrooks, J. M. 2010. Atmospheric oxygen level and the evolution of insect body size. - Proceedings of the Royal Society, series B, 277: 1937-1946.

Harrison, J. F. \& Lighton, J. R. B. 1998. Oxygen-sensitive flight metabolism in the dragonfly Erythemis simplicicollis. - Journal of Experimental Biology 201: 1739-1744.

Hilton, J. \& Cleal, C. J. 2007. The relationship between Euramerican and Cathaysian tropical floras in the Late Palaeozoic: Palaeobiogeographical and palaeogeographical implications. - Earth Science Reviews 85: 3-4.

Johansson, F., Crowley, P. H. \& Brodin, T. 2005. Sexual size dimorphism and sex ratios in dragonflies (Odonata). - Biological Journal of the Linnean Society 86 (4): 507-513.

Kaiser, A., Klok, C. J., Socha, J. J., Lee, W.-K., Quinlan, M. C. \& Harrison, J. F. 2007. Increase in tracheal investment with beetle size supports hypothesis of oxygen limitation on insect gigantism. - Proceedings of the National Academy of Sciences of the United States of America 104 (32): 13198-13203.

Kerp, H. 2000. The modernization of landscapes during the Late Paleozoic - Early Mesozoic. In Gastaldo, R. A. \& diMichele, W. A. (eds) Phanerozoic Terrestrial ecosystems. Paleontological Society Papers: pp. $79-113$.

Kirkton, S. D. 2007. Effects of insect body size on tracheal structure and function. - Advances on Experimental Medicine and Biology 618: 221-228.

Kukalová, J. 1964. To the morphology of the oldest known dragonfly Erasipteron larischi Pruvost, 1933. - Vestnik ustredniho ustavu geologickeho 39: 463-464.
Kukalová, J. 1969. Revisional study of the order Palaeodictyoptera in the Upper Carboniferous shales of Commentry, France. Part 2. Psyche 76: 439-486.

Labandeira, C. C. 2006. Silurian to Triassic plant and hexapod clades and their associations: new data, a review, and interpretations. Arthropod Systematics \& Phylogeny 64 (1): 53-94.

Labandeira, C. C. \& Phillips, T. L. 2002. Stem boring and petiole galls from Pennsylvanian tree ferns of Illinois, USA: implications for the origin of the borer and galler functional-feeding-groups and Holometabolous insects. - Palaeontographica Abteilung A 264: $1-84$.

Lanham, U. 1965. Uninominal nomenclature. - Systematic Zoology 14 (2): 144

Lesnikowska, A. D. 1990. Evidence of herbivory in tree-fern petioles from the Calhoun Coal (Upper Pennsylvanian) of Illinois. - Palaios 5: 76-80.

Liu Yushuang, Ren Dong \& Prokop, J. 2009. Discovery of a new Namurian archaeorthopterid from Ningxia, China (Insecta: Archaeorthoptera). - Zootaxa 2032: 63-68.

Lu Liwu, Fang Xiaosi, Ji, Shuan \& Pang Qiqing 2002. A contribution to the knowledge of the Namurian in Ningxia. - Acta Geoscientia Sinica 23 (2): 165-168.

Makarieva, A. M., Gorshkov, V. G. \& Li Bailian 2005. Gigantism, temperature and metabolic rate in terrestrial poikilotherms. - Proceedings of the Royal Society B, Biological Sciences, 272 (1578): $2325-2328$.

Martynov, A. V. 1932. New Permian Palaeoptera with the discussion of some problems of their evolution. - Travaux de l'Institut paléozoologique de l'Académie des Sciences de l'URSS, Moscow 1: $1-44$.

Meunier, F. 1908. Nouveaux insectes des schistes houillers de Commentry (cinquième note). - Annales de la Société scientifique de Bruxelles 32: 241-244.

Montañez, I. P., Tabor, N. J., Niemeier, D., DiMichele, W. A., Frank, T. D., Fielding, C. R., Isbell, J. L., Birgenheier, L. P. \& Rygel, M. C. 2007. $\mathrm{CO}_{2}$-forced climate and vegetation instability during the Late Palaeozoic glaciation. - Science 315: 87-91.

Nel, A., Fleck, G., Garrouste, R. \& Gand, G. 2008. The Odonatoptera of the Late Permian Lodève basin (Insecta). - Journal of Iberian Geology 34: 115-122.

Nel, A., Fleck, G., Garrouste, R., Gand, G., Lapeyrie, J., Bybee, S. M. \& Prokop, J. 2009. Revision of Permo-Carboniferous griffenflies (Insecta: Odonatoptera: Meganisoptera) based upon new species and redescription of selected poorly known taxa from Eurasia. - Palaeontographica Abteilung A 289 (4-6): $89-121$.

Palisot de Beauvois, A. M. F. J. 1805-1821. Insectes recueillis en Afrique et en Amérique dans les royaumes d'Oware et de Bénin, à Saint-Domingue et dans les États-unis, pendant les années 1786-1797. Paris.

Patterson, C. 1982. Morphological characters and homology. In Joysey, K. A. \& Friday, A. F. (eds) Problems of phylogenetic reconstruction. Academic Press, London: pp. 21-74.

Peng Decheng, Hong Youchong \& Zhang Zhijun 2005. Namurian insects (Diaphanopterodea) from Qilianshan Mountains, China. Geological Bulletin of China 24 (3): 219-234.

Pritykina, L. N. 1981. Novye triasovye strekozy srednej Azii. In Vishniakova, V. N., Dlussky, G. M. \& Pritykina, L. N. (eds) Novye iskopaemye nasekomye s Terrotorii SSSR. Trudy Paleontologicheskogo instituta, Akademiya Nauk SSSR, 183, Moscow: pp. 542.

Prokop, J. \& Nel, A. 2009. Systematic position of Triplosoba, hitherto the oldest mayfly, from the Upper Carboniferous of Commentry in Central France (Insecta: Palaeodictyopteroidea). - Systematic Entomology 34 (4): 610-615.

Prokop, J. \& Ren Dong 2007. New significant fossil insects from the Upper Carboniferous of Ningxia in northern China (Insecta: Pa- 
laeodictyoptera, Archaeorthoptera). - European Journal of Entomology 104 (2): 267-275.

Pruvost, P. 1933. Un ancêtre des libellules dans le terrain houiller the Tchécoslovaquie. - Annales de la Société Géologique du Nord 58: $149-155+$ pl. 5 .

Rambur, M. P. 1842. Histoire naturelle des Insectes. Névroptères. Roret, Paris.

Ren Dong, Nel, A. \& Prokop, J. 2008. New early griffenfly, Sinomeganeura huangheensis from the Late Carboniferous of northern China (Meganisoptera: Meganeuridae). - Insect Systematics and Evolution 38: 223-229.

Riek, E. F. \& Kukalová-Peck, J. 1984. A new interpretation of dragonfly wing venation based upon Early Upper Carboniferous fossils from Argentina (Insecta, Odonatoidea) and basic character states in pterygota wings. - Canadian Journal of Zoology 62 (6): 1150-1166.

Schneider, J. W. 1983. Taxonomie, Biostratigraphie und Palökologie der Blattodea-Fauna aus dem Stefan von Commentry (Frankreich) - Versuch einer Revision. - Freiberger Forschungshefte C, 384: 77-100.

Schneider, J. W., Körner, F., Roscher, M. \& Kroner, U. 2006. Permian climate development in the northern peri-Tethys area - The Lodève basin, French Massif Central, compared in a European and global context. - Palaeogeography, Palaeoclimatology, Palaeoecology 240 (1-2): 161-183.

Scudder, S. H. 1893. Insect fauna of the Rhode Island coal field. U.S. - Geological Survey Bulletin 101: 1-21.

Sellards, E. H. 1906. Types of Permian insects. Part 1: Odonata. American Journal of Science (4) 22 (4): 249-258.
Su Ya, Zhang Zhijun \& Hong Youchong 2012. Two new ancient dragonflies (Insecta: Odonatoptera) from the Namurian of Ningxia, China. - Insect Systematics and Evolution 43 (1): 1-10.

Van der Linden, P. L. 1825. Monographiae Libellularum Europaearum specimen. Franck, Brussels.

Whalley, P. E. S. 1979. New species of Protorthoptera and Protodonata (Insecta) from the Upper Carboniferous of Britain, with a comment on the origin of wings. - Bulletin of the British Museum (Natural History) (Geology) 32 (1): 85-90.

Zessin, W. 1983. Zur Taxonomie der jungpaläozoischen Familie Meganeuridae (Odonata) unter Einbezihung eines Neufundes aus dem Stephan C der Halleschen Mulde (DDR). - Freiberger Forschungshefte C, 384: 58-76.

Zessin, W. 2006. Zwei neue Insektenreste (Megasecoptera, Odonatoptera) aus dem Westfalium D (Oberkarbon) des Piesberges bei Osnabrück, Deutschland. - Virgo, Mitteilungsblatt des Entomologischen Vereins Mecklenburg 9 (1): 37-45.

Zessin, W., Brauckmann, B. \& Gröning, E. 2011. Rasnitsynala sigambrorum gen. et sp. n., a small odonatopterid ("Eomeganisoptera", Erasipteridae") from the early Late Carboniferous of Hagen-Vorhalle (Germany). - Zookeys 130: 57-66.

Zhang Zhijun, Hong Youchong, Lu Liwu, Fang Xiaoso \& Jin Yuegao 2006. Shenzhousia qilianshanensis gen. et sp. nov. (Protodonata, Meganeuridae), a giant dragonfly from the Upper Carboniferous of China. - Progress in Natural Science 16 (3): 328-330.

Zhang Zhijun, Schneider, J. W. \& Hong Youchong 2012. The most ancient roach (Blattida): a new genus and species from the earliest Late Carboniferous (Namurian) of China, with discussion on the phylomorphogeny of early blattids. - Journal of Systematic Palaeontology: 1-14. 